\title{
Effect of amyloid beta on ATP-binding cassette transporter expression and activity in porcine brain microvascular endothelial cells
}

DOI:

10.1016/j.bbagen.2018.07.021

\section{Document Version}

Accepted author manuscript

Link to publication record in Manchester Research Explorer

Citation for published version (APA):

Shubbar, M. H., \& Penny, J. I. (2018). Effect of amyloid beta on ATP-binding cassette transporter expression and activity in porcine brain microvascular endothelial cells. Biochimica et Biophysica Acta (BBA)-General Subjects, 1862(10), 2314-2322. https://doi.org/10.1016/j.bbagen.2018.07.021

\section{Published in:}

Biochimica et Biophysica Acta (BBA)-General Subjects

\section{Citing this paper}

Please note that where the full-text provided on Manchester Research Explorer is the Author Accepted Manuscript or Proof version this may differ from the final Published version. If citing, it is advised that you check and use the publisher's definitive version.

\section{General rights}

Copyright and moral rights for the publications made accessible in the Research Explorer are retained by the authors and/or other copyright owners and it is a condition of accessing publications that users recognise and abide by the legal requirements associated with these rights.

\section{Takedown policy}

If you believe that this document breaches copyright please refer to the University of Manchester's Takedown Procedures [http://man.ac.uk/04Y6Bo] or contact uml.scholarlycommunications@manchester.ac.uk providing relevant details, so we can investigate your claim.

\section{OPEN ACCESS}




\section{Effect of amyloid beta on ATP-Binding Cassette transporter expression and activity in porcine brain microvascular endothelial cells}

Maryam H. Shubbar ${ }^{a *}$, Jeffrey I. Penny ${ }^{a}$

${ }^{\mathrm{a}}$ Division of Pharmacy \& Optometry, University of Manchester, Manchester M13 9PT, UK

*Corresponding author: Maryam H Shubbar at Division of Pharmacy \& Optometry,

University of Manchester, Manchester M13 9PT, UK

E-mail address: Maryam.shubbar@postgrad.manchester.uk 


\begin{abstract}
Background: Deposition of amyloid- $\beta$ peptide $\left(A \beta_{(1-42)}\right)$ within the brain is characteristic of Alzheimer's disease. Little is known of the effects of $A \beta_{(1-42)}$ on blood-brain barrier (BBB) ATP-binding Cassette (ABC) efflux transporters which influence BBB permeability. The effects of $\mathrm{A} \beta_{(1-42)}$ on $\mathrm{ABCB} 1, \mathrm{ABCC} 5$ and $\mathrm{ABCG} 2$ activity and expression and pregnane $\mathrm{X}$ receptor (PXR) and constitutive androstane receptor (CAR) transcription factors expression were determined in primary porcine brain endothelial cells (PBECs).
\end{abstract}

Methods: The effect of $A \beta_{(1-42)}$ on transporter activity was determined by measurement of intracellular accumulation of the fluorescent probes calcein (ABCB1), GS-MF (ABCC5) and Hoechst 33342 (ABCG2). Expression of transporters and transcription factors was assessed by Western blotting.

Results: Treatment of PBECs with $\mathrm{A} \beta_{(1-42)}$ significantly decreased activity of ABCB1 $\left(\mathrm{A} \beta_{(1-}\right.$ 42) at $10 \mu \mathrm{g} / \mathrm{ml}, 25 \mu \mathrm{g} / \mathrm{ml}$ and $50 \mu \mathrm{g} / \mathrm{ml}), \operatorname{ABCC} 5\left(\mathrm{~A} \beta_{(1-42)}\right.$ at $25 \mu \mathrm{g} / \mathrm{ml}$ and $\left.50 \mu \mathrm{g} / \mathrm{ml}\right)$ and ABCG2 $\left(\mathrm{A} \beta_{(1-42)}\right.$ at $10 \mu \mathrm{g} / \mathrm{ml}, 25 \mu \mathrm{g} / \mathrm{ml}$ and $\left.50 \mu \mathrm{g} / \mathrm{ml}\right) . \quad A \beta_{(1-42)}$ also significantly decreased expression of ABCB1 (p<0.05 at $25 \mu \mathrm{g} / \mathrm{ml}$ and $50 \mu \mathrm{g} / \mathrm{ml})$, ABCG2 (p<0.05 at $25 \mu \mathrm{g} / \mathrm{ml}$ and $\mathrm{p} \leq 0.001$ at $50 \mu \mathrm{g} / \mathrm{ml}), \operatorname{ABCC} 5(\mathrm{p}<0.05$ at $25 \mu \mathrm{g} / \mathrm{ml}$ and $50 \mu \mathrm{g} / \mathrm{ml})$, PXR $(\mathrm{p}<0.05$ at 10 $\mu \mathrm{g} / \mathrm{ml}, 25 \mu \mathrm{g} / \mathrm{ml}$ and $\left.50 \mu \mathrm{g} / \mathrm{ml} \mathrm{A} \beta_{(1-42)}\right)$ and $\mathrm{CAR}\left(\mathrm{p}<0.05\right.$ at $25 \mu \mathrm{g} / \mathrm{ml}$ and $\left.50 \mu \mathrm{g} / \mathrm{ml} \mathrm{A} \beta_{(1-42)}\right)$. Conclusion: $\mathrm{A} \beta_{(1-42)}$ inhibits multiple $\mathrm{ABC}$ transporters and PXR and CAR in PBECs.

General Significance: $A \beta_{(1-42)}$ reduces $A B C$ transporter activity and expression in $B B B$ endothelial cells and has the potential to influence BBB permeability characteristics.

Keys words: $\mathrm{ABCB} 1, \mathrm{ABCG} 2, \mathrm{ABCC} 5$, nuclear receptors, Amyloid- $\beta$, Alzheimer's disease, porcine brain endothelial cells. 


\section{Introduction}

The blood-brain barrier (BBB) forms the highly selective interface between the central nervous system (CNS) and the systemic circulation, regulating molecular transport and maintaining an optimal environment for neuronal and glial function [1,2]. The polyspecific ATP-binding cassette (ABC) efflux transporters ABCB1 (MDR1, P-glycoprotein), ABCC5 (multidrug resistance-related protein 5) and ABCG2 (breast cancer resistance protein) are highly expressed in BBB endothelial cells, and actively transport an array of xenobiotics, including many therapeutic drugs, resulting in reduced CNS penetration [3,4,5]. ABC efflux transporters also transport a variety of endogenous compounds including glucocorticoid, cytokines, bilirubin, cholesterol and lipid [6,7] and, notably, ABCB1 has been reported to transport the amyloid- $\beta\left(\mathrm{A} \beta_{(1-42)}\right)$ peptide [8].

Alzheimer's disease is a progressive fatal neurodegenerative disorder and the most common form of dementia. One of the key pathological characteristics of Alzheimer's disease is aggregation of the $A \beta_{(1-42)}$ peptide within the brain, leading to production of cytotoxic oligomers [9], plaque formation [10] and subsequent neurological deficit [11]. Amyloid- $\beta$ is transported across the BBB, both from blood to brain and brain to blood, with influx into the brain mediated by the receptor for advanced glycation end products (RAGE) and clearance via the low density lipoprotein-related protein (LRP) receptor 1 (LRP1) [12], such that the peptide is in a dynamic equilibrium [13]. Furthermore, it has been postulated that reduced $A \beta_{(1-42)}$ clearance from the brain, i.e. reduced efflux transport of $A \beta_{(1-42)}$, may be associated with accumulation of $A \beta_{(1-42)}$ in Alzheimer's disease [14].

Whilst it has been demonstrated $\mathrm{A} \beta_{(1-42)}$ reduces $\mathrm{ABCB} 1$ expression and activity in brain endothelial cells $[8,15,16]$, and $A \beta_{(1-42)}$ either has no effect [16] or up-regulates [17] ABCG2 expression, no studies yet report the effects of $A \beta_{(1-42)}$ on the activity or expression of $\mathrm{BBB}$ ABCC5. The pregnane $X$ receptor (PXR) and the constitutive androstane receptor (CAR) are widely expressed in BBB brain endothelial cells $[18,19,20]$ and are key regulators of $\mathrm{ABC}$ transporter expression. ABC efflux transporter substrates, and inhibitors, act as PXR and CAR ligands [21,22] however to date, there are no reports of the effects of $A \beta_{(1-42)}$ on PXR and CAR expression.

In the present study the effects of $A \beta_{(1-42)}$ on the activities of $A B C B 1, A B C G 2$ and $\mathrm{ABCC} 5$, and on the expression of $\mathrm{ABCB} 1, \mathrm{ABCG} 2, \mathrm{PXR}$ and $\mathrm{CAR}$ were investigated in a well-characterised $\mathrm{BBB}$ model comprised of primary porcine brain endothelial cells 
$[23,24,25]$ to obtain a better understanding on the potential effect of $A \beta_{(1-42)}$ on $\mathrm{BBB}$ function.

\section{Materials and methods}

\subsection{Chemicals}

$\mathrm{A} \beta_{(1-42)}$ peptide was purchased from Cellmano Biotech Limited (China). Dulbecco's phosphate buffered saline (PBS), dimethyl sulfoxide (DMSO), Neutral Red powder, Thioflavin $\mathrm{T}$, heparin sodium salt from porcine intestinal mucosa, trypsin-EDTA solution, verapamil, Ko143, penicillin/streptomycin and puromycin dihydrochloride were purchased from Sigma-Aldrich (UK). Calcein and HEPES were purchased from Invitrogen (Paisley, Scotland). C219 anti-ABCB1 monoclonal antibody was purchased from MERCK (Darmstadt Germany). BXP-53 anti-ABCG2 monoclonal antibody, anti-MRP5 antibody (ab115327), anti-PXR (ab192579), anti-constitutive androstane receptor antibody (ab186869) and antivinculin (ab129002) were purchased from Abcam (Cambridge, UK). Mouse IgG anti- $\beta$-actin antibody, Collagen type I (rat tail) and fibronectin (human) were purchased from SLS Ltd Nottingham, UK). DMEM (low glucose, no pyruvate, no glutamine, no phenol red) and DMEM (high glucose, no pyruvate), were purchased from Life Technologies Ltd (Paisley, UK). Cell culture plastic ware was obtained from Greiner Bio-one (Stonehouse, UK) and plasma-derived serum from First Link (Birmingham, UK). Bradford protein assay reagent and Western blotting materials were obtained from Bio-Rad (Hemel Hempstead, UK).

\subsection{Isolation and culture of PBECs}

Isolation of porcine brain microvessels was based on the method described by Skinner et al.; [23,26]. Microvessels were either immediately maintained in culture or stored at liquid nitrogen. Microvessels were seeded into 6-well plates pre-coated with $100 \mu \mathrm{g} / \mathrm{ml}$ type I rat tail collagen and $7.5 \mu \mathrm{g} / \mathrm{ml}$ human fibronectin and maintained in growth medium composed of DMEM (low glucose without phenol red) supplemented with $100 \mathrm{U} / \mathrm{ml}$ penicillin and 100 $\mathrm{mg} / \mathrm{ml}$ streptomycin, $2 \mathrm{mM}$ glutamine, $10 \%$ (v/v) plasma derived serum and $125 \mu \mathrm{g} / \mathrm{ml}$ heparin in a humidified atmosphere at $37{ }^{\circ} \mathrm{C}$ with $5 \% \mathrm{CO}_{2}$ for $24 \mathrm{~h}$. Microvessels were treated for $48 \mathrm{~h}$ with puromycin dihydrochloride, $4 \mu \mathrm{g} / \mathrm{ml}$, and maintained in growth medium 
and astrocyte- conditioned medium (1:1) for 6 days, to allow proliferation of PBECs. PBECs were then used for Western blotting studies or subcultured into 96-well plates.

\subsection{Culture of astrocytes}

The CTX-TNA2 rat astrocyte cell line (passages 8-20) was maintained in DMEM supplemented with $10 \%(\mathrm{v} / \mathrm{v})$ foetal bovine serum with $100 \mathrm{U} / \mathrm{ml}$ penicillin and $100 \mathrm{mg} / \mathrm{ml}$ streptomycin at a seeding density of $1 \times 10^{6}$ cells per $75 \mathrm{~cm}^{2}$ flask. When cells reached confluency, astrocyte conditioned medium (ACM) was collected and stored at $-20{ }^{\circ} \mathrm{C}$ until use.

2.4. Measurement of $\mathrm{ABCB} 1, \mathrm{ABCG} 2$ and $\mathrm{ABCC} 5$ functional activity

Functional activity of $\mathrm{ABCB} 1, \mathrm{ABCG} 2$ and $\mathrm{ABCC} 5$ was measured as described previously [24,27]. PBECs in 96-well plates were treated with either $10 \mu \mathrm{g} / \mathrm{ml}, 25 \mu \mathrm{g} / \mathrm{ml}$ or $50 \mu \mathrm{g} / \mathrm{ml} \mathrm{A} \beta_{(1-42)}$ in treatment medium (DMEM low glucose without phenol red supplemented with $1 \%$ (v/v) FBS and $2 \mathrm{mM} \mathrm{L}$-glutamine) for $48 \mathrm{~h}$ at $37^{\circ} \mathrm{C}$ in $5 \% \mathrm{CO}_{2}$. Cells were initially incubated with the above medium containing either $10 \mu \mathrm{M}$ verapamil (ABCB1 inhibitor) [28], $0.5 \mu \mathrm{M}$ Ko143 (ABCG2 inhibitor) [29] or $25 \mu \mathrm{M}$ MK571 (ABCC5 inhibitor) [30] for $30 \mathrm{~min}$ at $37^{\circ} \mathrm{C}$. The above media were then replaced with media plus inhibitors containing either calcein-AM, $0.5 \mu \mathrm{M}$ (to measure ABCB1 activity), Hoechst 33342, $1 \mu \mathrm{M}$, (to measure $\mathrm{ABCG} 2$ activity) and CMFDA, $4 \mu \mathrm{M}$, (to measure ABCC5 activity). Following a 30 min incubation at $37{ }^{\circ} \mathrm{C}$ PBECs were washed twice with warm PBS and intracellular fluorescence of calcein (excitation $484 \mathrm{~nm}$; emission $530 \mathrm{~nm}$ ), Hoechst 33342 (excitation 370 $\mathrm{nm}$; emission $450 \mathrm{~nm}$ ) and GS-MF (excitation $492 \mathrm{~nm}$; emission $516 \mathrm{~nm}$ ) measured using a Safire multiplate reader (Tecan, Germany). Relative fluorescence units were normalised for the protein content of each individual well and functional activity is represented as \% RFU/ug protein compared to non-treated control.

\subsection{Cell viability}

The effect of $A \beta_{(1-42)}$ on PBECs viability was determined using the Neutral Red assay [31]. PBECs in 96-well plates were treated with either $10 \mu \mathrm{g} / \mathrm{ml}, 25 \mu \mathrm{g} / \mathrm{ml}$ or $50 \mu \mathrm{g} / \mathrm{ml} \mathrm{A} \beta_{(1-}$ 
42) in treatment medium for $48 \mathrm{~h}$ at $37^{\circ} \mathrm{C}$ in $5 \% \mathrm{CO}_{2}$. Following treatment, the medium was removed and replaced with DMEM (low glucose without phenol red supplemented with 2 $\mathrm{mM}$ L-glutamine) containing Neutral Red, $40 \mu \mathrm{g} / \mathrm{ml}$. Cells were incubated for $2 \mathrm{~h}$ at $37^{\circ} \mathrm{C}$ in a humidified atmosphere with $5 \% \mathrm{CO}_{2}$, washed twice with PBS, $150 \mu$ of destain solution (1 $\%(\mathrm{v} / \mathrm{v})$ acetic acid in $50 \%(\mathrm{v} / \mathrm{v})$ ethanol) added to each well and plates agitated rapidly for 15 minutes on a rocking platform. Fluorescence intensity was measured with a Safire multiplate reader (Tecan, Germany), with excitation and emission wavelengths of 530 and $645 \mathrm{~nm}$, respectively.

2.6. Measurement of $A \beta_{(1-42)}$ peptide monomer aggregation using the Thioflavin $\mathrm{T}$ assay

Aggregation of $A \beta_{(1-42)}$ peptide was monitored using the Thioflavin $\mathrm{T}$ assay as described by Kokkoni et al. with modifications [32]. Briefly, $A \beta_{(1-42)}$ monomer peptide was dissolved in treatment medium to concentrations of $10 \mu \mathrm{g} / \mathrm{ml}, 25 \mu \mathrm{g} / \mathrm{ml}$ and $50 \mu \mathrm{g} / \mathrm{ml}$ and the peptide incubated at $37^{\circ} \mathrm{C}$ (Galaxy 14S Incubator, New Brunswick, UK). At 0, 24, 48, 72 and $96 \mathrm{~h}$, a $10 \mu \mathrm{l}$ sample of $\mathrm{A} \beta_{(1-42)}$ peptide solution was transferred to 96-well plates, $90 \mu 1$ of $4 \mu \mathrm{M}$ Thioflavin $\mathrm{T}$ solution added and fluorescence intensity was measured with a Safire multiplate reader (Tecan, Germany) with a $10 \mathrm{~s}$ shake prior to each fluorescence reading, and excitation and emission wavelengths of $440 \mathrm{~nm}$ and $495 \mathrm{~nm}$, respectively. During data analysis the fluorescent reading of the vehicle control (DMEM with Thioflavin T but no A $\beta_{(1-42)}$ peptide) was subtracted from the test $A \beta_{(1-42)}$ and Thioflavin T fluorescent reading.

\subsection{Effect of $A \beta_{(1-42)}$ on $A B C B 1, A B C G 2$ and $A B C C 5$ functional activity}

Porcine brain endothelial cells were treated with $10 \mu \mathrm{g} / \mathrm{ml}, 25 \mu \mathrm{g} / \mathrm{ml}$ and $50 \mu \mathrm{g} / \mathrm{ml} \mathrm{A} \beta_{(1-42)}$ for $1 \mathrm{~h}, 24 \mathrm{~h}$ and $48 \mathrm{~h}$ at $37{ }^{\circ} \mathrm{C}$ in $5 \% \mathrm{CO}_{2}$. The effect of $\mathrm{A} \beta_{(1-42)}$ on ABCB1, ABCG2 and ABCC5 activity was measured spectrofluorometrically as described in section 2.4.

\subsection{Western blotting}

Porcine brain endothelial cell lysates were prepared using Cellytic M lysis buffer (SigmaAldrich, UK) with protease inhibitor cocktail (Sigma-Aldrich, UK), $1 \mu 1$ inhibitor cocktail per $\mathrm{ml}$ of lysis buffer. Cell lysates were centrifuged at $15,000 \mathrm{~g}$ for $15 \mathrm{~min}$ at $4{ }^{\circ} \mathrm{C}$ and the protein 
content of the supernatant determined by the Bradford method using a standard curve of bovine serum albumin [33]. Equal quantities of lysate protein, $15 \mu \mathrm{g}$, were separated using 6 $\%, 8 \%$ and $10 \%$ SDS-polyacrylamide gels for the detection of ABCB1, ABCG2 and both PXR and CAR\% respectively, $50 \mu \mathrm{g}$ protein was separated using 6\% SDS-polyacrylamide gels for the detection of $\mathrm{ABCC} 5$ and proteins transferred onto polyvinylidene difluoride membranes in $10 \mathrm{mM}$ CAPS buffer, $\mathrm{pH} 11$. Membranes were blocked with $5 \%$ (w/v) low fat milk and incubated overnight at $4{ }^{\circ} \mathrm{C}$ with either $\mathrm{C} 219$ mouse monoclonal antibody for detection of ABCB1 (1:50), BXP-53 monoclonal antibodyfor detection of ABCG2 (1:100), anti-MRP polyclonal antibody detection of ABCC5 (1:500) and mouse anti- $\beta$-actin-Nterminal monoclonal antibody $(1: 25,000)$ for detection of $\beta$-actin. PXR was detected with anti PXR polyclonal antibody (1:1000) and CAR with anti-constitutive androstane receptor polyclonal antibody (1:1000). Mouse anti-rabbit anti vinculin antibody, at a dilution of 1:10,000, were used to detect vinculin. Membranes were subsequently incubated with HRPconjugated secondary antibody for protein detection. Western blots were developed using Enhanced Chemiluminescence reagent (Biorad, UK), images obtained using a ChemiDoc imaging system (Bio-Rad, UK) and analysed with the ImageJ software (NIH, USA).

\subsection{Statistical analysis}

All experiments were carried out at least four times, unless stated. Data are expressed as mean \pm standard deviation and SPSS v20 (IBM) was used to carry out unpaired t-tests. A Pvalue of less than 0.05 is considered significant.

\section{Results}

3.1. Determination of $\mathrm{ABCB} 1, \mathrm{ABCG} 2$ and $\mathrm{ABCC} 5$ functional activity in porcine brain endothelial cells

Initial fluorimetric studies were carried out to determine $\mathrm{ABCB} 1, \mathrm{ABCG} 2$ and $\mathrm{ABCC} 5$ functional activity. Treatment of cells with the ABCB1 inhibitor verapamil significantly increased intracellular accumulation of the fluorescent probe calcein by 7-fold, figure 1 . Similarly, treatment with the ABCG2 inhibitor Ko143 increased intracellular accumulation of 
the ABCG2 substrate Hoechst 33342 by 2.1 -fold, whilst the ABCC5 inhibitor MK571 significantly increased intracellular levels of the ABCC5 substrate GS-MF by 2.4 fold, figure 1.

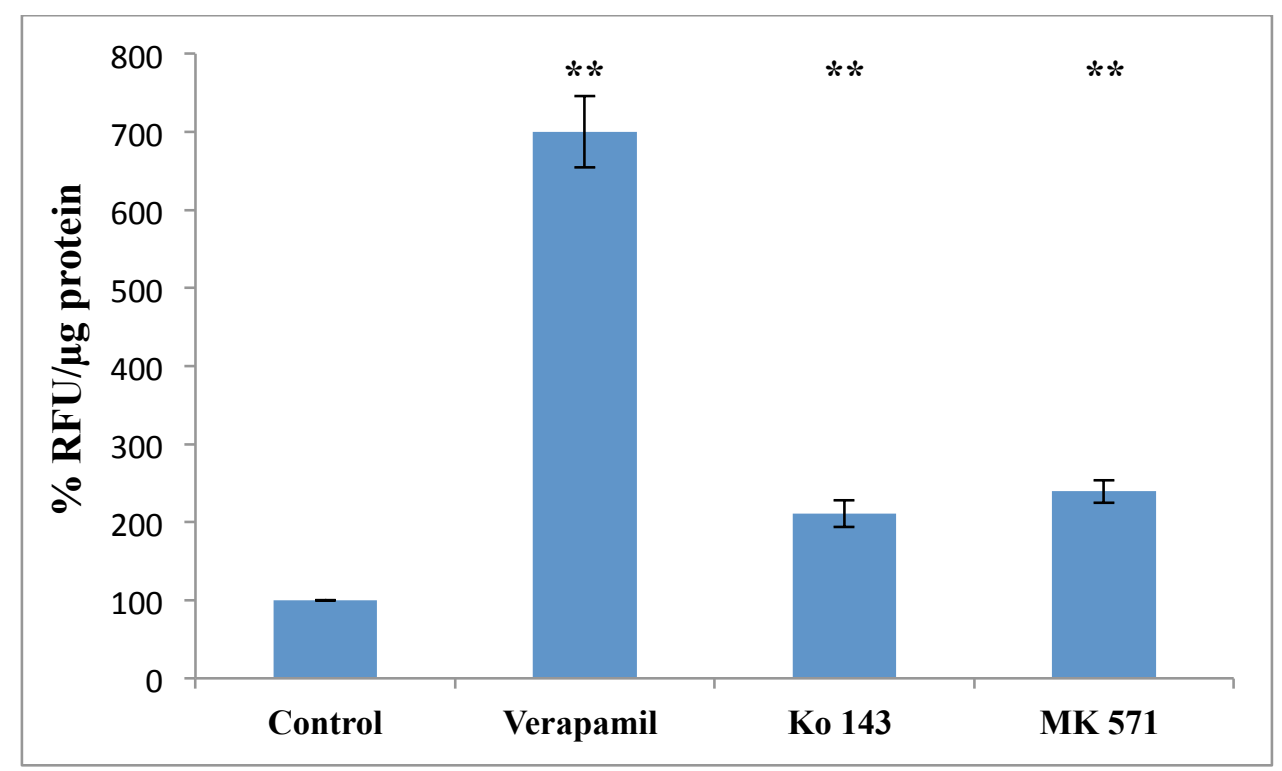

Fig. 1. Determination of ABCB1, ABCG2 and ABCC5 functional activity in PBECs. Intracellular accumulation of calcein, Hoechst 33342 and GS-MF in control cells and cells pre-treated with ABCB1 inhibitor (verapamil), ABCG2 inhibitor (Ko143) and ABCC5 inhibitor (MK571). Data were analysed using unpaired Student's t-test and are presented as the mean \pm SD of 8 independent experiments, with 4 replicates in each experiment, ** $\mathrm{p} \leq 0.001$

3.2. Effect of $A \beta_{(1-42)}$ on the viability of porcine brain endothelial cells

The viability of porcine brain endothelial cells exposed to $A \beta_{(1-42)}$ was determined using the Neutral Red assay. No significant toxicity was observed when cells were exposed to 10 $\mu \mathrm{g} / \mathrm{ml}, 25 \mu \mathrm{g} / \mathrm{ml}$ and $50 \mu \mathrm{g} / \mathrm{ml} \mathrm{A} \beta_{(1-42)}$ over a $48 \mathrm{~h}$ period, figure 2 . 


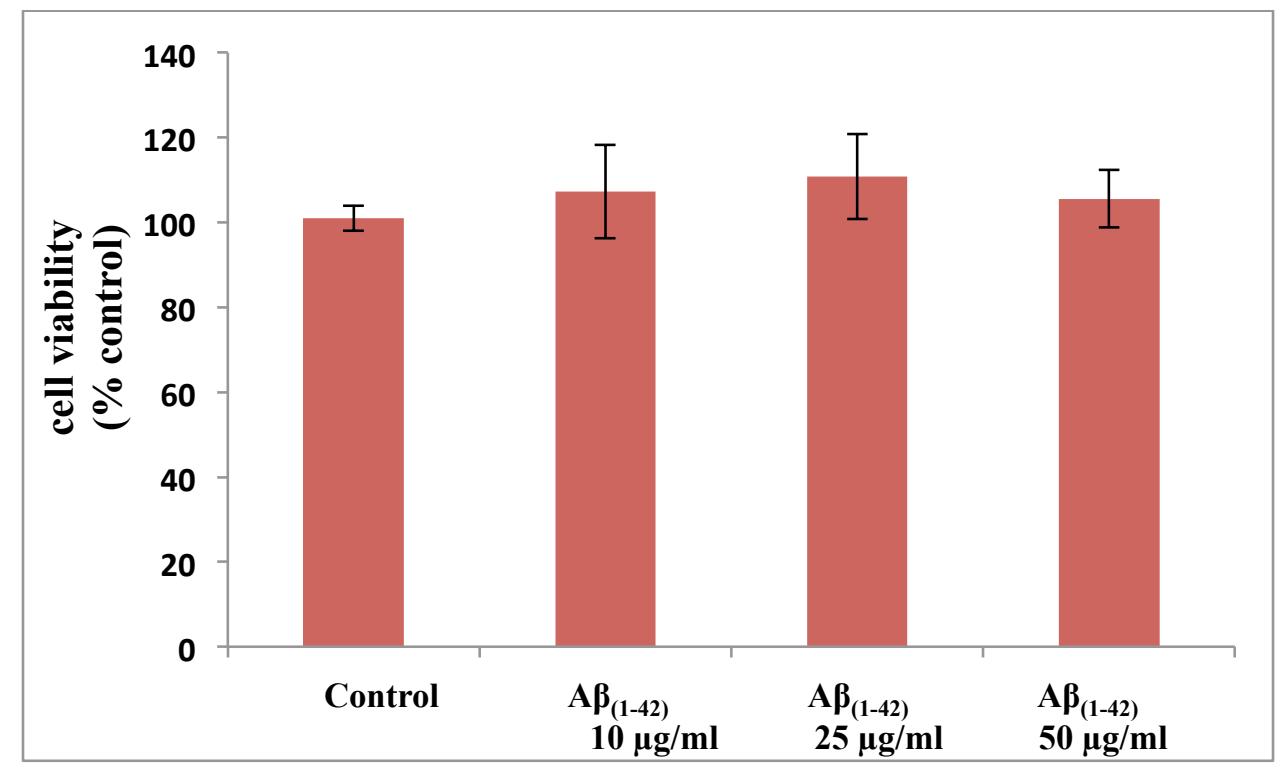

Fig. 2. The effect of $A \beta_{(1-42)}$ on porcine brain endothelial cell viability. The fluorescence intensity of Neutral Red was measured in control cells and cells pre-treated for $48 \mathrm{~h}$ with $10 \mu \mathrm{g} / \mathrm{ml}, 25 \mu \mathrm{g} / \mathrm{ml}$ and $50 \mu \mathrm{g} / \mathrm{ml} \mathrm{A} \beta_{(1-42)}$. Data were analysed using unpaired Student's t-test and are presented as the mean \pm SD of 4 independent experiments, with 4 replicates in each experiment

\section{3. $\mathrm{A} \beta_{(1-42)}$ aggregation}

Initial studies were carried out to establish if $A \beta_{(1-42)}$ underwent aggregation in the cell culture conditions employed in this study. There was a significant increase in fluorescent intensity of Thioflavin $\mathrm{T}$ over time when $\mathrm{A} \beta_{(1-42)}$ at $25 \mu \mathrm{g} / \mathrm{ml}$ and $50 \mu \mathrm{g} / \mathrm{ml}$ was incubated in PBEC treatment medium, indicating a time-dependent increase in $A \beta_{(1-42)}$ aggregation. However at $10 \mu \mathrm{g} / \mathrm{ml} \mathrm{A} \beta_{(1-42)}$ the fluorescent intensity was very low and no significant changes in fluorescence were observed over time, figure 3. 


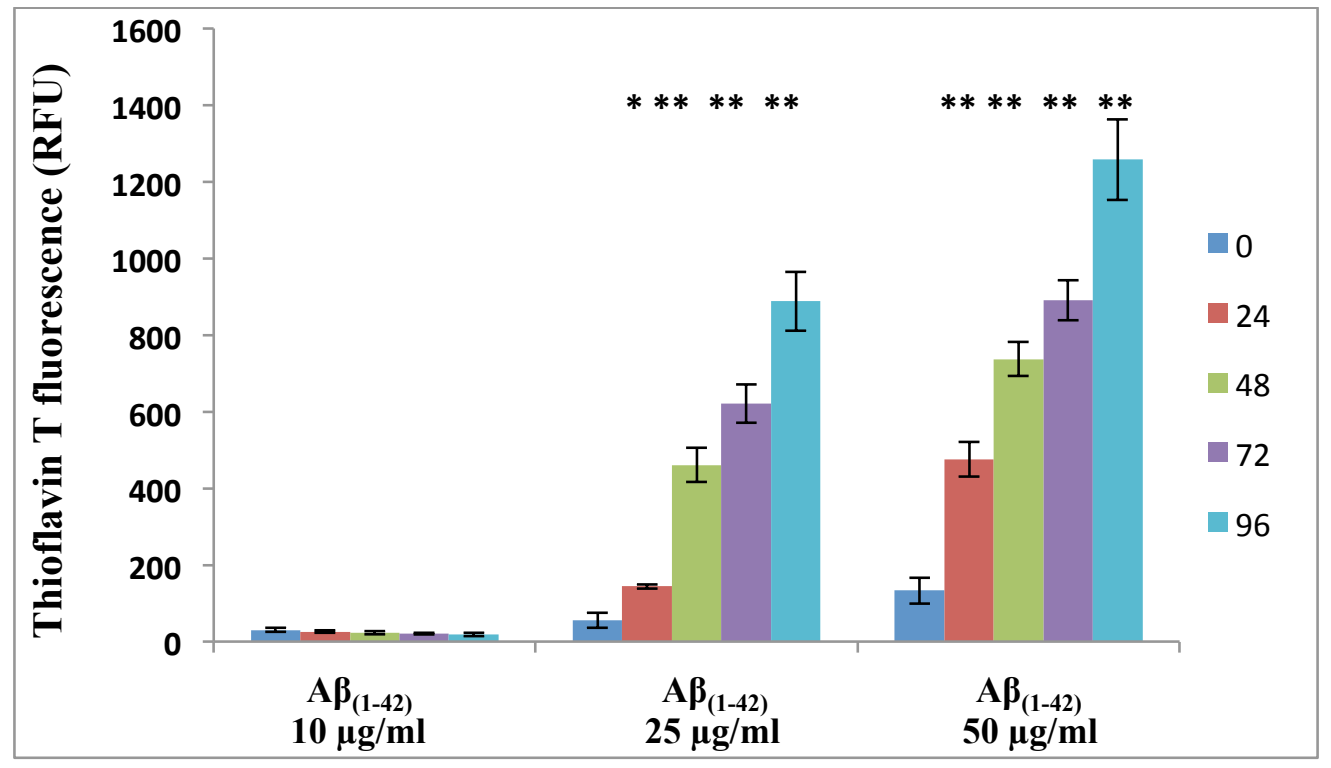

Fig. 3. Aggregation $\mathbf{A \beta}_{(1-42)}$ in PBEC treatment medium. $A \beta_{(1-42)}$ peptide solution was freshly prepared at concentrations of $10 \mu \mathrm{g} / \mathrm{ml}, 25 \mu \mathrm{g} / \mathrm{ml}$ and $50 \mu \mathrm{g} / \mathrm{ml}$ and incubated for $0,24,48,72$ and 96 $\mathrm{h}$ in PBEC treatment medium, and a $10 \mu \mathrm{l}$ sample of $\mathrm{A} \beta_{(1-42)}$ peptide mixed with $90 \mu \mathrm{l}$ of $4 \mu \mathrm{M}$ Thioflavin T. Data are expressed as relative fluorescence units (RFU) and are the mean \pm SD of 3 independent experiments with 4 replicates in each experiment. Data were analysed using unpaired Student's t-test, ${ }^{*} \mathrm{p}<0.05,{ }^{* *} \mathrm{p} \leq 0.001$.

\subsection{Effect of $\mathrm{A} \beta_{(1-42)}$ on $\mathrm{ABCB} 1$ functional activity}

Studies were carried out to determine the effect of $A \beta_{(1-42)}$ exposure on the functional activity of the ABCB1 efflux transporter. Treatment with $10 \mu \mathrm{g} / \mathrm{ml}, 25 \mu \mathrm{g} / \mathrm{ml}$ and $50 \mu \mathrm{g} / \mathrm{ml}$ $\mathrm{A} \beta_{(1-42)}$ for $1 \mathrm{~h}$ and $24 \mathrm{~h}$ significantly increased calcein accumulation in porcine brain endothelial cells, indicating reduced ABCB1 activity, figure 4. At $48 \mathrm{~h}$ exposure, there was no significant difference in calcein accumulation in cells pre-treated with $10 \mu \mathrm{g} / \mathrm{ml} \mathrm{A} \beta_{(1-42)}$

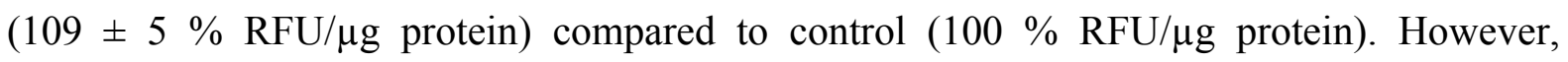
treatment with $25 \mu \mathrm{g} / \mathrm{ml}$ and $50 \mu \mathrm{g} / \mathrm{ml} \mathrm{A} \beta_{(1-42)}$ significantly increased calcein accumulation to $132 \pm 9 \% \mathrm{RFU} / \mu \mathrm{g}$ protein and $144 \pm 5 \% \mathrm{RFU} / \mu \mathrm{g}$ protein respectively, compared with

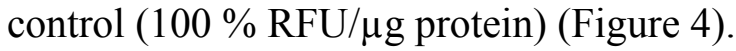




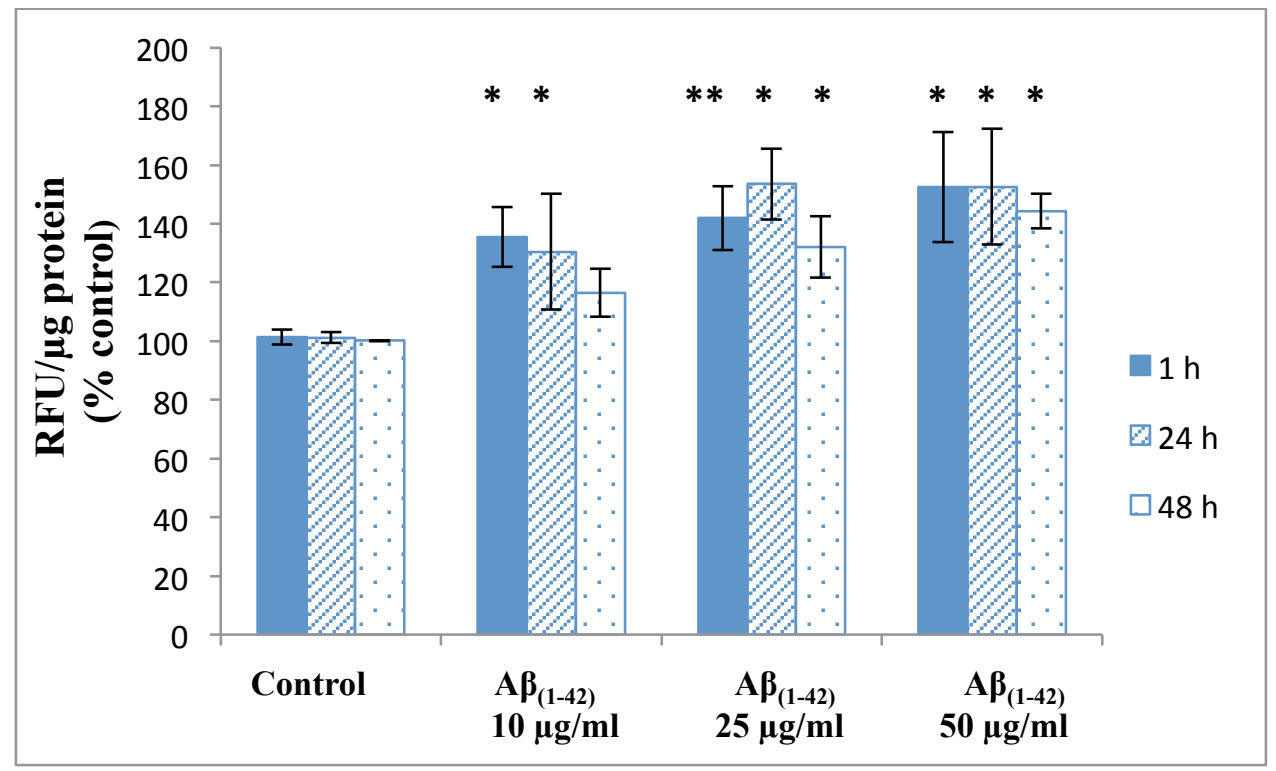

Fig. 4. Effects of $\mathbf{A \beta}_{(1-42)}$ on $\mathbf{A B C B 1}$ functional activity. Intracellular accumulation of calcein in control cells and cells pre-treated for $1 \mathrm{~h}$ (solid bars), $24 \mathrm{~h}$ (striped bars) and $48 \mathrm{~h}$ (dotted bars) with $10 \mu \mathrm{g} / \mathrm{ml}, 25 \mu \mathrm{g} / \mathrm{ml}$ and $50 \mu \mathrm{g} / \mathrm{ml} \mathrm{A} \beta_{(1-42)}$. Data were analysed using unpaired Student's t-test and are presented as the mean \pm SD of 4 independent experiments, with 4 replicates in each experiment, ${ }^{*} \mathrm{p}<0.05,{ }^{* *} \mathrm{p} \leq 0.001$.

\subsection{Effect of $A \beta_{(1-42)}$ on $\mathrm{ABCB} 1$ expression}

Western blotting studies were carried out to determine the effect of $A \beta_{(1-42)}$ on $A B C B 1$ expression in PBECs. Exposure to $A \beta_{(1-42)}$ at $10 \mu \mathrm{g} / \mathrm{ml}, 25 \mu \mathrm{g} / \mathrm{ml}$ and $50 \mu \mathrm{g} / \mathrm{ml}$ for $1 \mathrm{~h}$ did not significantly affect ABCB1 expression compared to non-treated control cells, figure 4. Whilst treatment with $\mathrm{A} \beta_{(1-42)}$ for $24 \mathrm{~h}$ at $10 \mu \mathrm{g} / \mathrm{ml}$ did not significantly alter $\mathrm{ABCB} 1$ expression, expression of the transporter in cells treated with $25 \mu \mathrm{g} / \mathrm{ml}$ and $50 \mu \mathrm{g} / \mathrm{ml} \mathrm{A} \beta_{(1-42)}$ for $24 \mathrm{~h}$ was significantly lower, $72.2 \% \pm 10 \%$ and $76.2 \% \pm 12 \%$ respectively, compared to control cells, figure 5. Similar observations were observed when PBECs were treated with $A \beta_{(1-42)}$ for $48 \mathrm{~h}$, with $\mathrm{A} \beta_{(1-42)}$ at $10 \mu \mathrm{g} / \mathrm{ml}$ having no significant effect on $\mathrm{ABCB} 1$ expression whilst 25 $\mu \mathrm{g} / \mathrm{ml}$ and $50 \mu \mathrm{g} / \mathrm{ml} \mathrm{A} \beta_{(1-42)}$ significantly reduced ABCB1 expression levels, figure 5. 
$1 \mathrm{~h}$

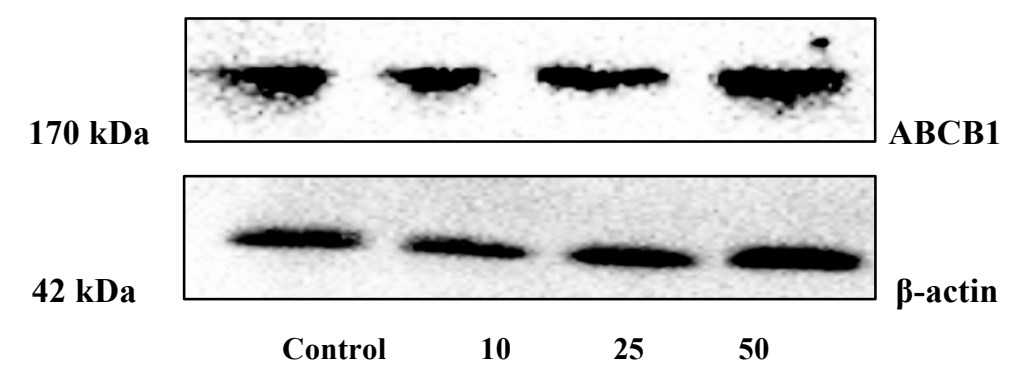

$A \beta_{(1-42)}(\mu g / m l)$

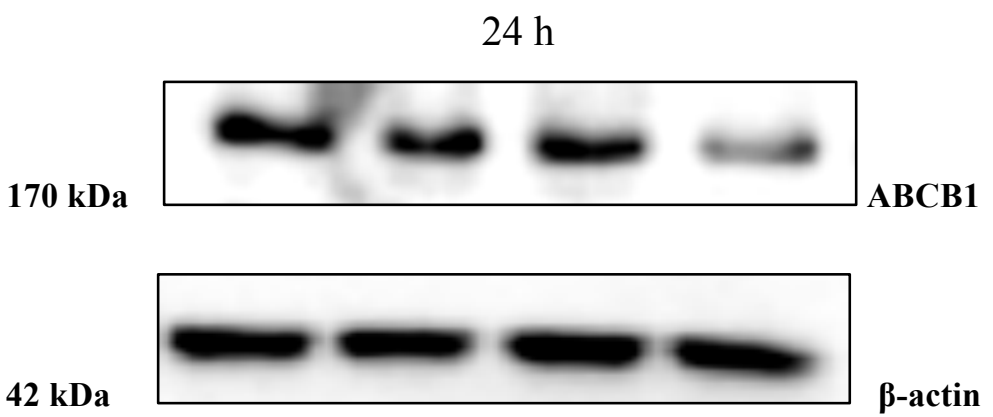

$\begin{array}{llll}\text { Control } & 10 & 25 & 50\end{array}$

$\mathrm{A \beta}_{(1-42)}(\mu \mathrm{g} / \mathrm{ml})$

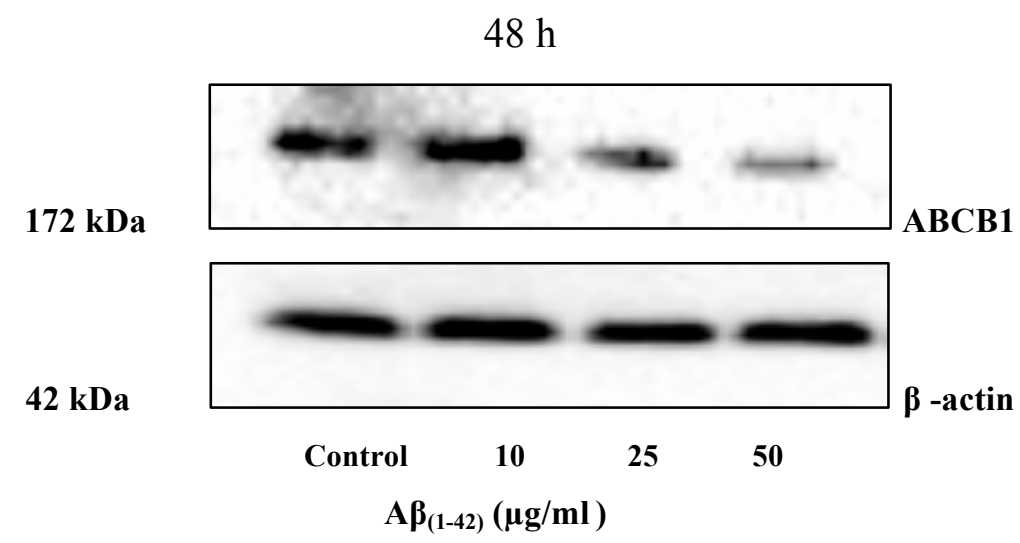

(B) 


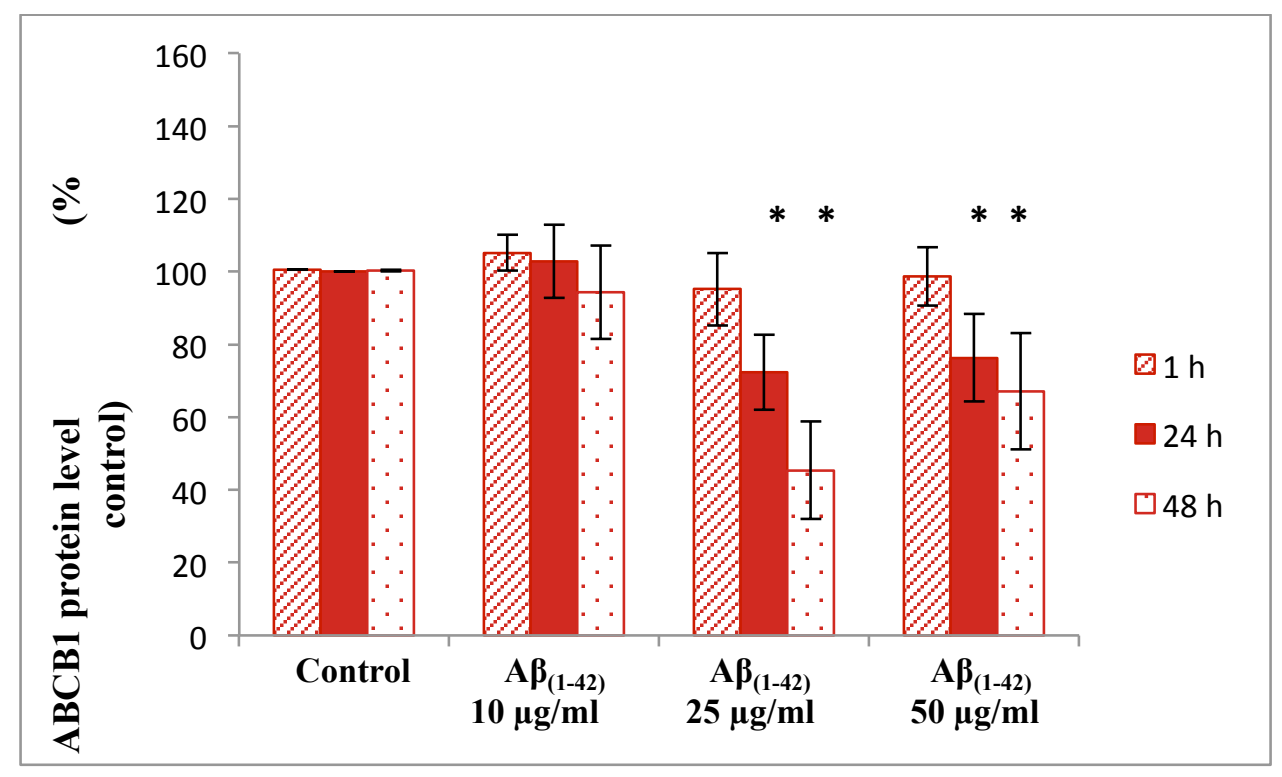

Fig. 5. Effect of $\mathbf{A \beta}_{(1-42)}$ on ABCB1 expression in PBECs. PBECs were treated for $1 \mathrm{~h}, 24 \mathrm{~h}$ and $48 \mathrm{~h}$ with $10 \mu \mathrm{g} / \mathrm{ml}, 25 \mu \mathrm{g} / \mathrm{ml}$ and $50 \mu \mathrm{g} / \mathrm{ml} \mathrm{A} \beta_{(1-42)}$. Panel (A) is a representative Western blot image and panel (B) densitometric data are normalised to $\beta$-actin and are presented as a percentage of untreated control cells. Data were analysed using unpaired Student's t-test and are presented as the mean \pm SD of 4 independent experiments, ${ }^{*} p<0.05$.

\subsection{Effect of $A \beta_{(1-42)}$ on $A B C G 2$ functional activity}

Studies were carried out to determine the effect of $A \beta_{(1-42)}$ exposure on the functional activity of the ABCG2 efflux transporter. Treatment with $10 \mu \mathrm{g} / \mathrm{ml}, 25 \mu \mathrm{g} / \mathrm{ml}$ and $50 \mu \mathrm{g} / \mathrm{ml}$ $\mathrm{A} \beta_{(1-42)}$ for $1 \mathrm{~h}$ and $24 \mathrm{~h}$ significantly increased Hoechst 33342 accumulation in porcine brain endothelial cells, indicating reduced ABCG2 activity, figure 6. At $48 \mathrm{~h}$ exposure, there was no significant difference in Hoechst 33342 accumulation in cells pre-treated with $10 \mu \mathrm{g} / \mathrm{ml}$

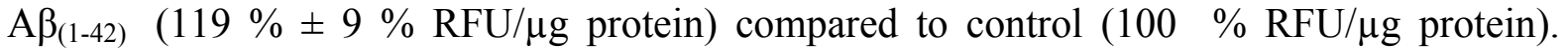
However, treatment with $25 \mu \mathrm{g} / \mathrm{ml}$ and $50 \mu \mathrm{g} / \mathrm{ml} \mathrm{A} \beta_{(1-42)}$ significantly increased Hoechst 33342 accumulation to $130.4 \% \pm 5 \% \mathrm{RFU} / \mu \mathrm{g}$ protein and $160 \% \pm 3 \% \mathrm{RFU} / \mu \mathrm{g}$ protein

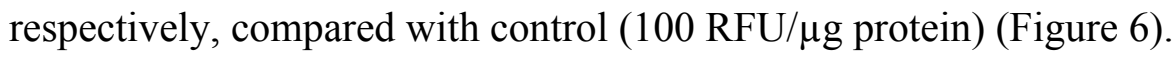




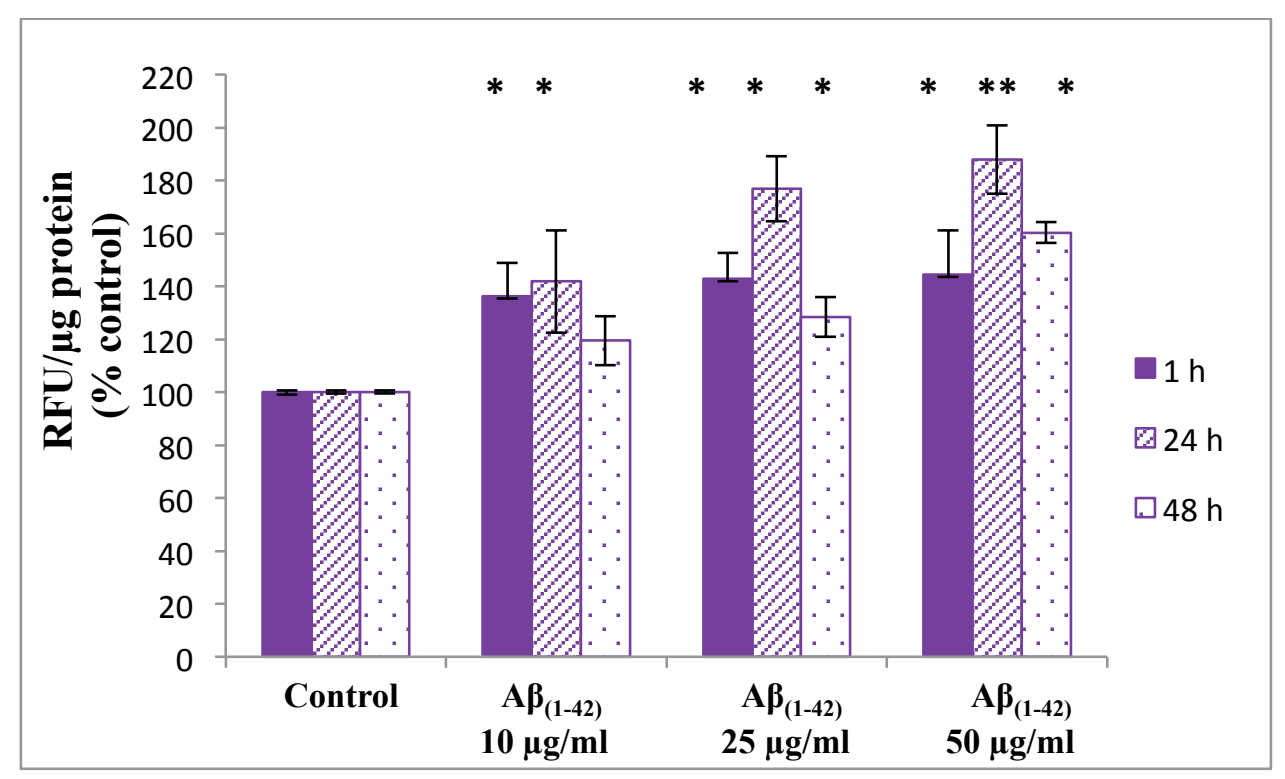

Fig. 6. Effects of $\mathbf{A \beta}_{(1-42)}$ on ABCG2 functional activity. Intracellular accumulation of Hoechst 33342 in control cells and cells pre-treated for $1 \mathrm{~h}$ (solid bars), $24 \mathrm{~h}$ (striped bars) and $48 \mathrm{~h}$ (dotted

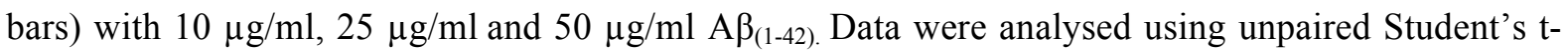
test and are presented as the mean $\pm \mathrm{SD}$ of 4 independent experiments, with 4 replicates in each experiment, ${ }^{*} \mathrm{p}<0.05,{ }^{*} \mathrm{p} \leq 0.001$.

\subsection{Effect of $A \beta_{(1-42)}$ on $A B C G 2$ expression}

Western blotting studies were carried out to determine the effect of $A \beta_{(1-42)}$ on ABCG2 expression in PBECs. Exposure to $\mathrm{A} \beta_{(1-42)}$ at $10 \mu \mathrm{g} / \mathrm{ml}, 25 \mu \mathrm{g} / \mathrm{ml}$ and $50 \mu \mathrm{g} / \mathrm{ml}$ for $1 \mathrm{~h}$ did not significantly affect ABCG2 expression compared to non-treated control cells, figure 7. Whilst treatment with $10 \mu \mathrm{g} / \mathrm{ml} \mathrm{A} \beta_{(1-42)}$ for $24 \mathrm{~h}$ did not significantly alter ABCG2 expression, expression levels of the transporter in cells treated with $25 \mu \mathrm{g} / \mathrm{ml}$ and $50 \mu \mathrm{g} / \mathrm{ml} \mathrm{A} \beta_{(1-42)}$ for 24 h were significantly lower, $81 \% \pm 1.5 \%$ and $65.2 \% \pm 16 \%$ respectively, compared to control cells, figure 7. Similar findings were observed when PBECs were treated with $A \beta_{(1-42)}$ for $48 \mathrm{~h}$, with $\mathrm{A} \beta_{(1-42)}$ at $10 \mu \mathrm{g} / \mathrm{ml}$ having no significant effect on ABCG2 expression whilst $25 \mu \mathrm{g} / \mathrm{ml}$ and $50 \mu \mathrm{g} / \mathrm{ml} \mathrm{A} \beta_{(1-42)}$ significantly reduced ABCG2 expression levels, figure 7. 
(A)

$1 \mathrm{~h}$
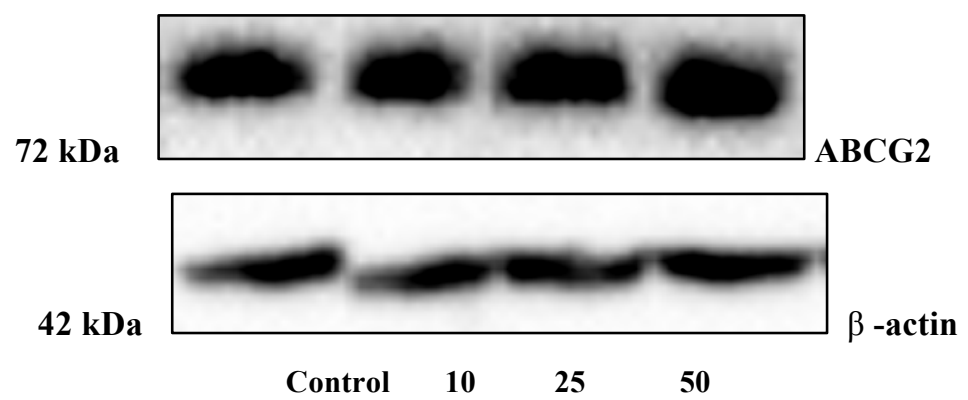

$A \beta_{(1-42)}(\mu \mathrm{g} / \mathrm{ml})$

$24 \mathrm{~h}$
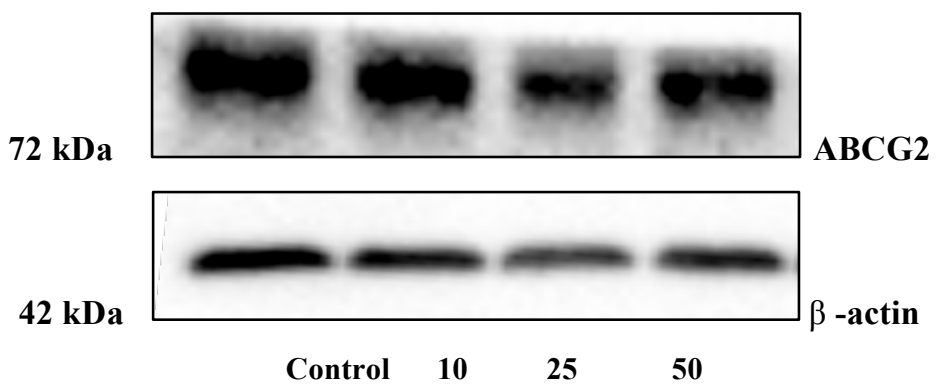

$A \beta_{(1-42)}(\mu \mathrm{g} / \mathrm{ml})$

$48 \mathrm{~h}$
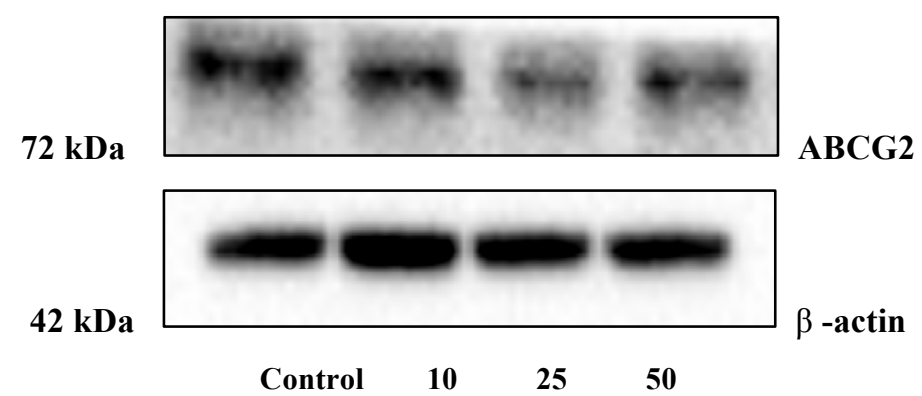

$\mathbf{A \beta}_{(1-42)}(\mu \mathrm{g} / \mathrm{ml})$ 
(B)

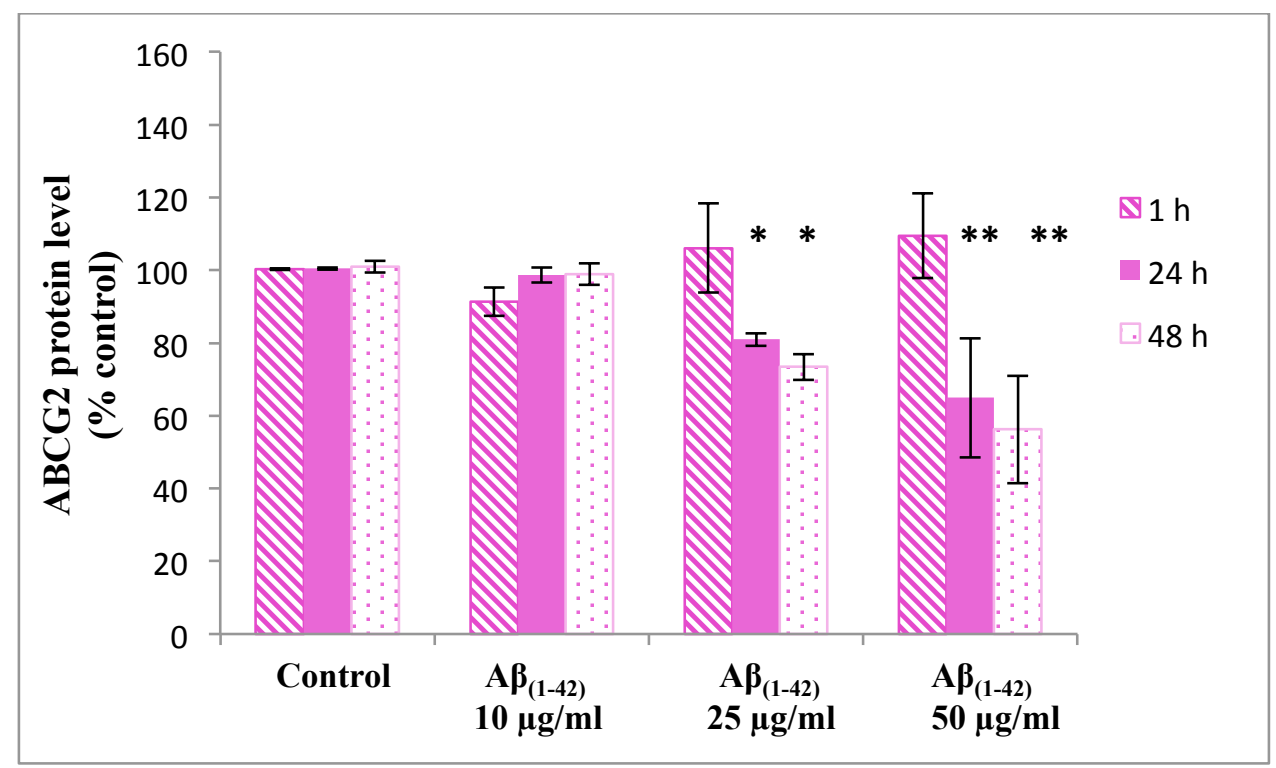

Fig. 7. Effect of $\mathbf{A \beta}_{(1-42)}$ on ABCG2 expression in PBECs. PBECs were treated for $1 \mathrm{~h}, 24 \mathrm{~h}$ and $48 \mathrm{~h}$ with $10 \mu \mathrm{g} / \mathrm{ml}, 25 \mu \mathrm{g} / \mathrm{ml}$ and $50 \mu \mathrm{g} / \mathrm{ml} \mathrm{A} \beta_{(1-42)}$. Panel (A) is a representative Western blot image and panel (B) densitometric data are normalised to $\beta$-actin and are presented as a percentage of untreated control cells. Data were analysed using unpaired Student's t-test and are presented as the mean \pm SD of 4 independent experiments, ${ }^{*} \mathrm{p}<0.05,{ }^{*} \mathrm{p} \leq 0.001$.

\subsection{Effect of $A \beta_{(1-42)}$ on ABCC5 functional activity}

Studies were carried out to determine the effect of $A \beta_{(1-42)}$ exposure on the functional activity of the ABCC5 efflux transporter. Treatment with $10 \mu \mathrm{g} / \mathrm{ml} \mathrm{A} \beta_{(1-42)}$ for $1 \mathrm{~h}, 24 \mathrm{~h}$ and $48 \mathrm{~h}$ did not significantly affect GS-MF accumulation in PBECs, figure 8. However, treatment with $25 \mu \mathrm{g} / \mathrm{ml}$ and $50 \mu \mathrm{g} / \mathrm{ml} \mathrm{A} \beta_{(1-42)}$ for $1 \mathrm{~h}, 24 \mathrm{~h}$ and $48 \mathrm{~h}$ significantly increased GS-MF accumulation (144\% $\% 9 \%$ and $141 \% \pm 7 \% \mathrm{RFU} / \mu \mathrm{g}$ protein for $1 \mathrm{~h}, 142 \% \pm 10 \%$ and $152 \% \pm 17 \% \mathrm{RFU} / \mu \mathrm{g}$ protein for $24 \mathrm{~h}$ and $144 \% \pm 12 \%$ and $143 \% \pm 6 \% \mathrm{RFU} / \mu \mathrm{g}$

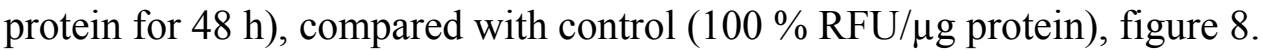




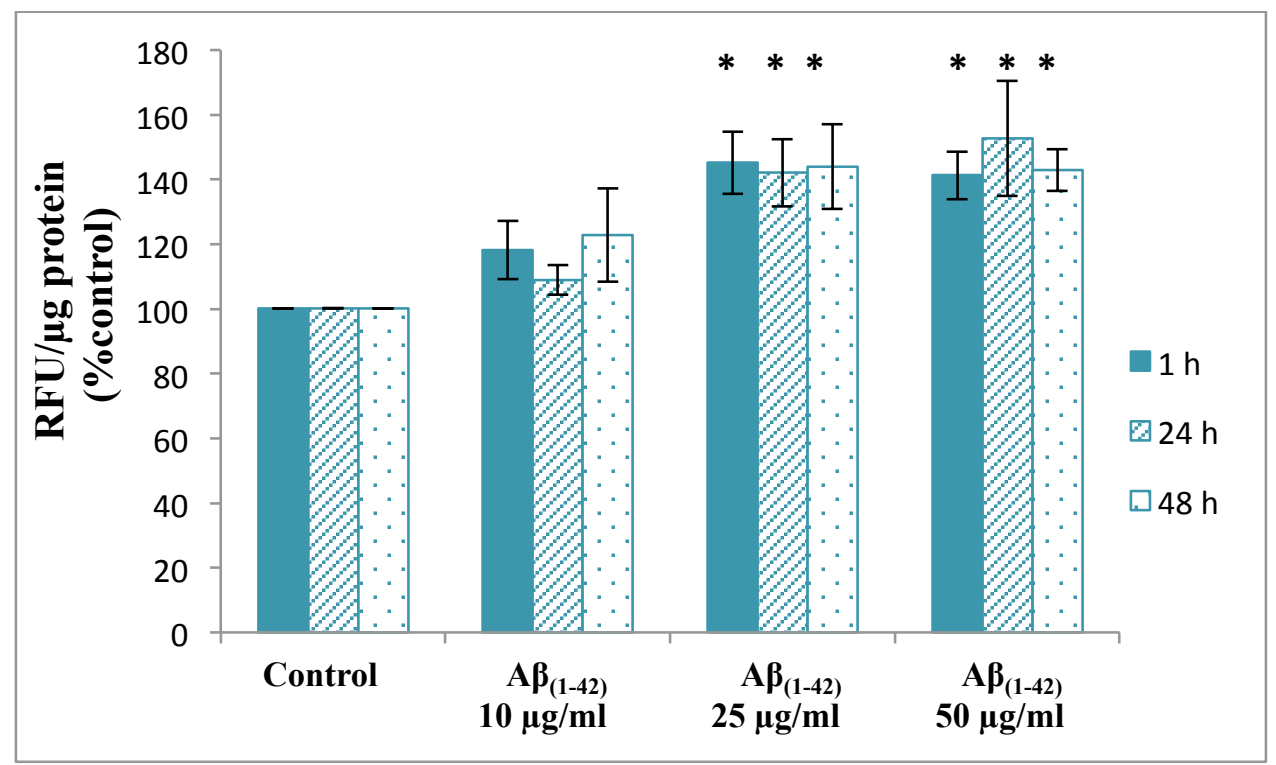

Fig. 8. Effects of $\mathbf{A} \boldsymbol{\beta}_{(1-42)}$ on ABCC5 functional activity. Intracellular accumulation of GS-MF in control cells and cells pre-treated for $1 \mathrm{~h}$ (solid bars), $24 \mathrm{~h}$ (striped bars) and $48 \mathrm{~h}$ (dotted bars) with $10 \mu \mathrm{g} / \mathrm{ml}, 25 \mu \mathrm{g} / \mathrm{ml}$ and $50 \mu \mathrm{g} / \mathrm{ml} \mathrm{A} \beta_{(1-42)}$. Data were analysed using Student's unpaired t-test and are presented as the mean \pm SD of 4 independent experiments, with 4 replicates in each experiment. $* \mathrm{p}<0.05$.

\subsection{Effect of $A \beta_{(1-42)}$ on $A B C C 5$ expression}

The effect of $\mathrm{A} \beta_{(1-42)}$ on $\mathrm{ABCC} 5$ expression in PBECs was determined by Western blotting. Exposure to $\mathrm{A} \beta_{(1-42)}$ at $10 \mu \mathrm{g} / \mathrm{ml}, 25 \mu \mathrm{g} / \mathrm{ml}$ and $50 \mu \mathrm{g} / \mathrm{ml}$ for $1 \mathrm{~h}$ did not significantly affect ABCC5 expression compared to non-treated control cells, figure 9. Whilst treatment with $10 \mu \mathrm{g} / \mathrm{ml} \mathrm{A} \beta_{(1-42)}$ for $24 \mathrm{~h}$ did not significantly alter ABCC5 expression, expression levels of the transporter in cells treated with $25 \mu \mathrm{g} / \mathrm{ml}$ and $50 \mu \mathrm{g} / \mathrm{ml}$ $\mathrm{A} \beta_{(1-42)}$ for $24 \mathrm{~h}$ were significantly lower, $55 \% \pm 10 \%$ and $65 \% \pm 9 \%$ respectively, compared to control cells, figure 9. Similar findings were observed when PBECs were treated with $A \beta_{(1-42)}$ for $48 \mathrm{~h}$, with $A \beta_{(1-42)}$ at $10 \mu \mathrm{g} / \mathrm{ml}$ having no significant effect on ABCC5 expression whilst $25 \mu \mathrm{g} / \mathrm{ml}$ and $50 \mu \mathrm{g} / \mathrm{ml} \mathrm{A} \beta_{(1-42)}$ significantly reduced ABCC5 expression levels, figure 9.

(A)

$1 \mathrm{~h}$

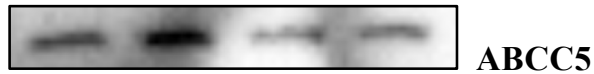




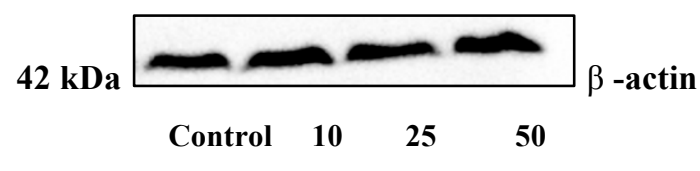

$\mathbf{A \beta}_{(1-42)}(\mu \mathrm{g} / \mathrm{ml})$

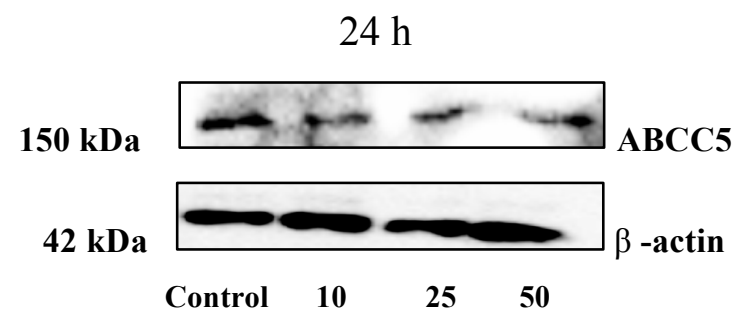

$A \beta_{(1-42)}(\mu \mathrm{g} / \mathrm{ml})$

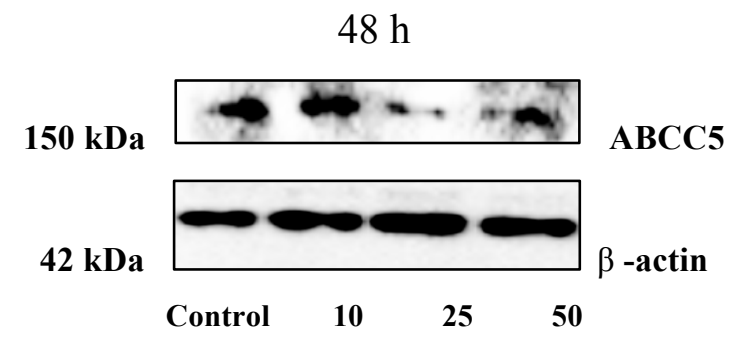

$A \beta_{(1-42)}(\mu \mathrm{g} / \mathrm{ml})$

(B)

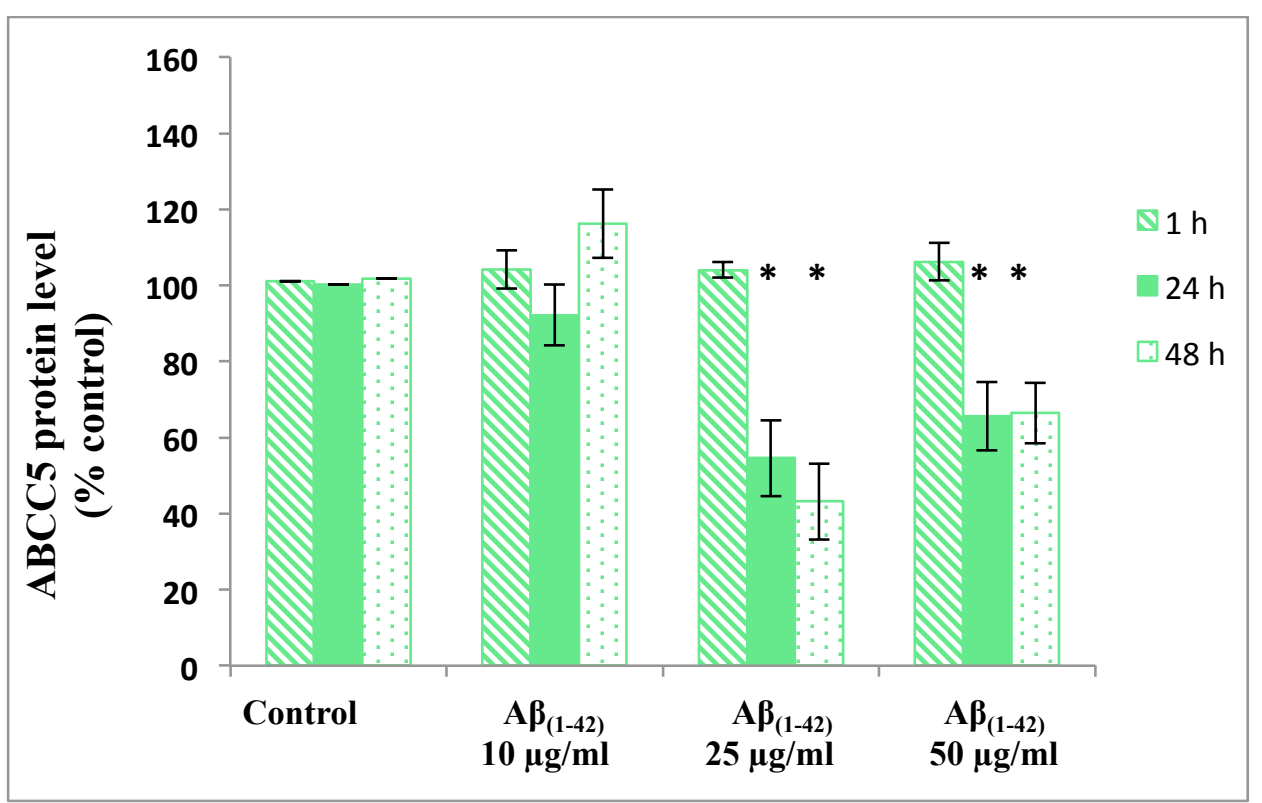


Fig. 9. Effect of $\mathbf{A \beta}_{(1-42)}$ on ABCC5 expression in PBECs. PBECs were treated for $1 \mathrm{~h}, 24 \mathrm{~h}$ and $48 \mathrm{~h}$ with $10 \mu \mathrm{g} / \mathrm{ml}, 25 \mu \mathrm{g} / \mathrm{ml}$ and $50 \mu \mathrm{g} / \mathrm{ml} \mathrm{A} \beta_{(1-42)}$. Panel (A) is a representative Western blot image and panel (B) densitometric data are normalised to $\beta$-actin and are presented as a percentage of untreated control cells. Data were analysed using unpaired Student's t-test and are presented as the mean \pm SD of 4 independent experiments, ${ }^{*} \mathrm{p}<0.05$.

\subsection{The effect of $A \beta_{(1-42)}$ on PXR and CAR expression}

This study demonstrates $A \beta_{(1-42)}$ significantly reduces $A B C B 1, A B C G 2$ and $A B C C 5$ expression in PBECs. The pregnane $\mathrm{X}$ receptor $(\mathrm{PXR})$ and constitutive androstane receptor (CAR) regulate $\mathrm{ABCB} 1, \mathrm{ABCG} 2$ and $\mathrm{ABCC} 2$ expression, although no reports document PXR- and CAR-mediated regulation of ABCC5. Therefore studies were carried out to determine the effect of $\mathrm{A} \beta_{(1-42)}$ on PXR and CAR expression. In initial control studies, treatment of PBECs with the PXR ligand rifampicin significantly increased both ABCB1 and ABCG2 expression and function, indicating functional PXR in PBECs (data not shown). Exposure of PBECs to $\mathrm{A} \beta_{(1-42)}$ at $10 \mu \mathrm{g} / \mathrm{ml}, 25 \mu \mathrm{g} / \mathrm{ml}$ and $50 \mu \mathrm{g} / \mathrm{ml}$ for $48 \mathrm{~h}$ significantly reduced PXR expression compared to non-treated control cells, figure 10 (A) and (B). Whilst treatment with $\mathrm{A} \beta_{(1-42)}$ for $48 \mathrm{~h}$ at $10 \mu \mathrm{g} / \mathrm{ml}$ did not significantly alter CAR expression, expression levels of CAR in PBECs treated with $25 \mu \mathrm{g} / \mathrm{ml}$ and $50 \mu \mathrm{g} / \mathrm{ml} \mathrm{A} \beta_{(1-42)}$ were significantly lower, $70 \% \pm 12 \%$ and $83 \% \pm 7 \%$ respectively, compared to control cells, figure $10(C)$ and (D).

(A)

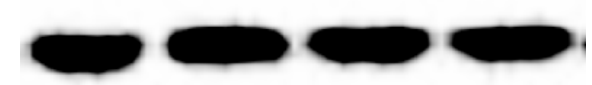




$$
\begin{array}{llrr}
\text { Control } & 10 & 25 & 50 \\
& \begin{array}{c}
\text { A } \beta_{(1-42)}(\mu \mathrm{g} / \mathrm{ml}) \\
\end{array}
\end{array}
$$

(B)

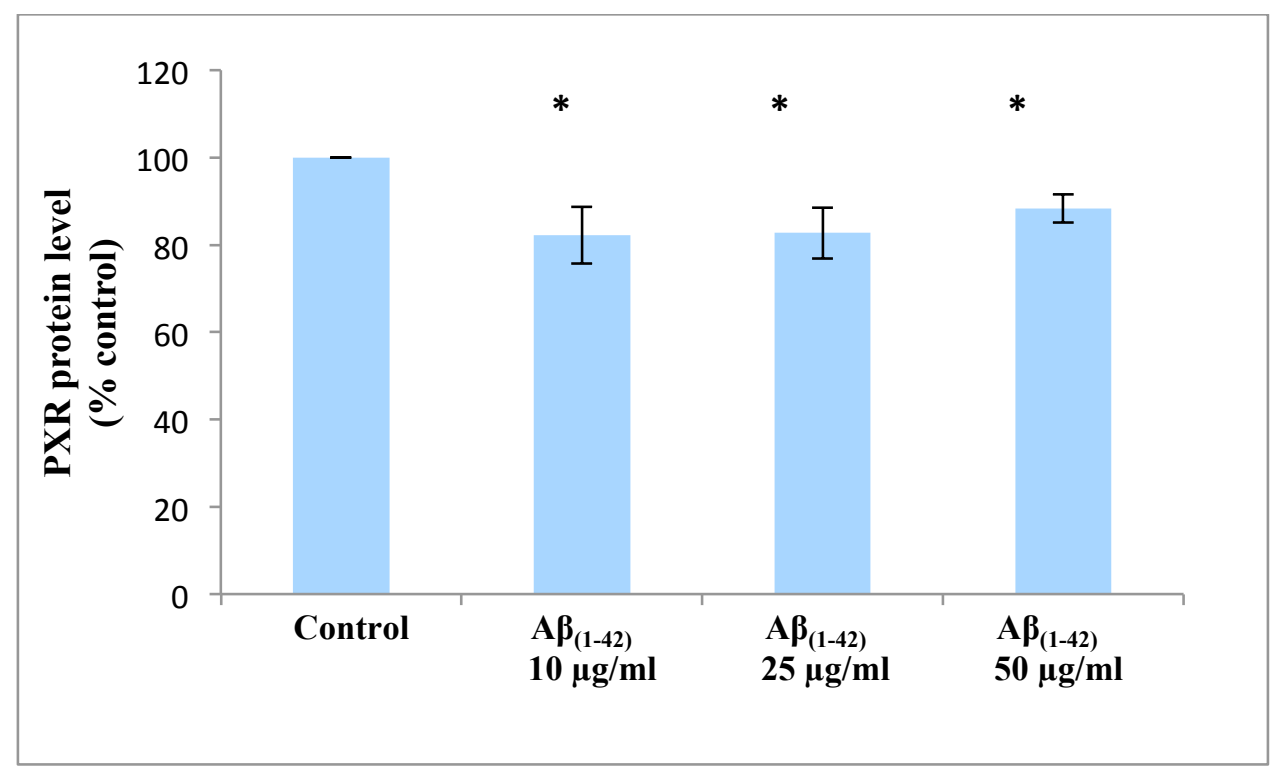

(C)

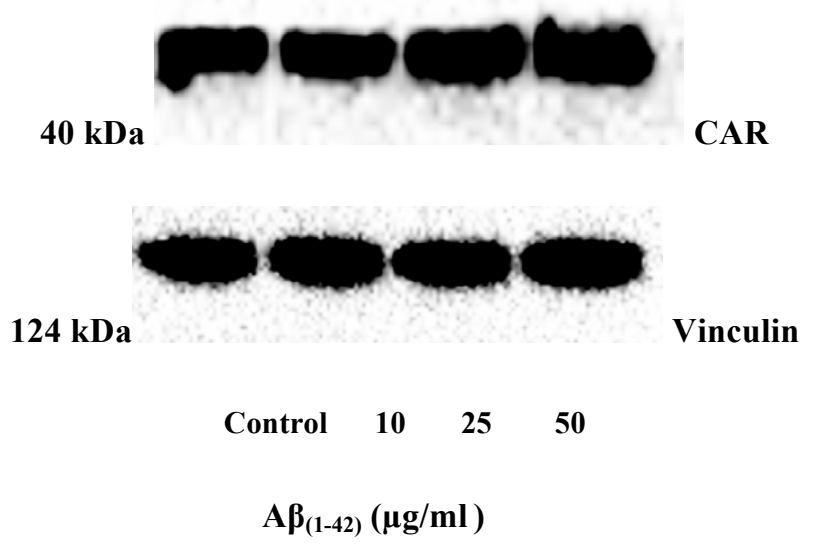

(D) 


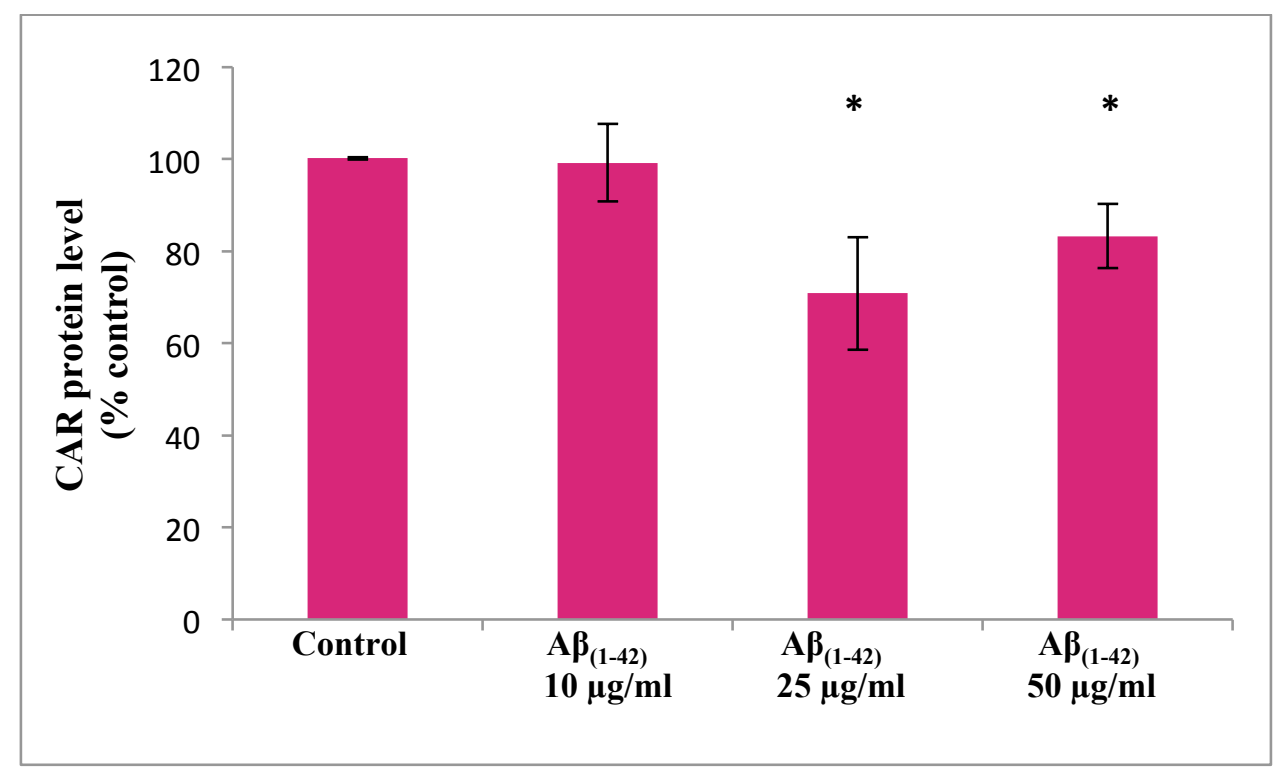

Fig. 10. Effects of $\mathbf{A \beta}_{(1-42)}$ on PXR and CAR expression in PBECs. PBECs were treated for $48 \mathrm{~h}$ with $10 \mu \mathrm{g} / \mathrm{ml}, 25 \mu \mathrm{g} / \mathrm{ml}$ and $50 \mu \mathrm{g} / \mathrm{ml} \mathrm{A} \beta_{(1-42)}$. Panels (A) and (C) are representative Western blot images of PXR and CAR respectively. Panel (B), PXR densitometric data, and panel (D), CAR densitometric data, are normalised to vinculin and are presented as a percentage of untreated control cells. Data were analysed using unpaired Student's t-test and are presented as the mean \pm SD of 4 independent experiments, ${ }^{*} \mathrm{p}<0.05$.

\section{Discussion}

One of the pathological hallmarks of Alzheimer's disease is deposition of amyloid- $\beta$ peptide $\left(\mathrm{A} \beta_{(1-42)}\right)$ into plaques, which accumulate within the brain, leading to neurological dysfunction [34,35]. Clearance of $A \beta_{(1-42)}$, from brain, across $\mathrm{BBB}$ endothelial cells, into the systemic circulation therefore represents a potential mechanism of reducing $A \beta_{(1-42)}$ levels within the CNS. The BBB functions to reduce brain exposure to endogenous and exogenous compounds, and polyspecific $\mathrm{ABC}$ efflux transporters, particularly $\mathrm{ABCB} 1, \mathrm{ABCG} 2$ and ABCC5, play a key role in this protective function. In this study we employed an in vitro model of the BBB, comprised of primary PBECs [23,24,25], to investigate the effects of $A \beta_{(1-42)}$ on the expression and function of $\mathrm{ABC}$ transporters and regulatory receptors in $\mathrm{BBB}$ endothelial cells.

Our previous studies employing this PBEC-based BBB model have reported expression and function of $\mathrm{ABCB} 1$ and $\mathrm{ABCG} 2$ [24], which are known to be highly expressed in the BBB $[36,37]$. The studies of Warren et al. report relatively high levels of ABCC5 mRNA in 
porcine brain endothelial cells [38] but did not investigate ABCC5 expression at the protein level. In addition, the study of Zhang et al. report that ABCC5 mRNA is more highly expressed in primary bovine brain microvessel endothelial cells than other members of the ABCC subfamily [39]. In human brain, ABCC5 has been reported to be the most highly expressed ABCC subfamily member in all human brain regions at the RNA level [40].

In the current study we successfully demonstrate expression of ABCC5 protein in PBECs, which is consistent with the study of Kubo et al. which reports ABCC5 expression by quantitative targeted proteomics in porcine brain capillary [41].

Initial studies were carried out to confirm functional activities of ABCB1, ABCG2 and ABCC5. Intracellular accumulation of calcein in PBECs pre-treated with the ABCB1 inhibitor verapamil was 7.8-fold higher than in control cells, indicating expression of active ABCB1. This finding is similar to those of Smith et al. who observed a 7.5-fold increase in rhodomine-123 intracellular accumulation in cells pre-treated with verapamil [42], whilst a 6fold increase in intracellular accumulation of calcein in PBECs has also been reported $[24,43]$.

ABCG2 function was assessed by measuring intracellular accumulation of Hoechst 33342 in PBECs pre-treated with the ABCG2 inhibitor Ko143. Ko143 treatment significantly increased intracellular Hoechst 33342 accumulation by 2-fold, which is in keeping with the 2fold increase reported by Cantrill et al. 2012 [24], and with the 1.6-fold increase in intracellular accumulation of the ABCG2 substrate mitoxantrone reported by Mahringer et al. [44].

The ABCC5 inhibitor MK571 significantly increased intracellular levels of the ABCC5 substrate GS-MF by 2.4-fold. This finding is in agreement with the study of Gutmann et al. which demonstrated a 3-fold increase in GS-MF levels in PBECs treated with MK571[27], and with studies which report MK571 increased intracellular accumulation of GS-MF by approximately 2-fold in the immortalized hBCEC cell line [45]. In initial studies, the specificity of the transporters for probe substrates was analysed. These studies found no significant change in intracellular accumulation of the ABCB1 substrate calcein-AM following treatment with ABCG2 and ABCC5 inhibitors. Similar findings were observed with ABCG2 and ABCC5 substrates, verifying a lack of overlap in substrate specificity (data not shown). Taken together, these findings demonstrate the PBECs employed in the current studies express key BBB-associated ABC efflux transporters. 
Prior to investigating the effect of $A \beta_{(1-42)}$ on ABCB1-, ABCG2- and ABCC5-mediated transport, cell viability studies were carried out. $A \beta_{(1-42)}$, at concentrations up to $50 \mu \mathrm{g} / \mathrm{ml}$, had no effect on PBECs viability. This is in agreement with studies reporting $A \beta_{(1-42)}$ at 50 $\mu \mathrm{g} / \mathrm{ml}$ had no significant effect, after $48 \mathrm{~h}$ treatment, on the viability of hCMEC/D3 brain endothelial cells [16], and is also consistent with the lack of effect of up to $100 \mu \mathrm{g} / \mathrm{ml} \mathrm{A} \beta_{(1-42)}$ on the viability of rat brain endothelial cells [46].

The current study presents the first experimental evidence that $A \beta_{(1-42)}$ significantly reduces $\mathrm{ABCB} 1$ activity in PBECs by direct inhibition (without an associated reduction in $\mathrm{ABCB} 1$ expression) in cells treated with $\mathrm{A} \beta_{(1-42)}$ for $1 \mathrm{~h}$.

Reduced ABCB1 activity at $24 \mathrm{~h}$ and $48 \mathrm{~h}$ is likely due to a combination of inhibition of $\mathrm{ABCB} 1$ by $\mathrm{A} \beta_{(1-42)}$ and by an $\mathrm{A} \beta_{(1-42)}$-mediated reduction in $\mathrm{ABCB} 1$ expression. The effects of $\mathrm{A} \beta_{(1-42)}$ on $\mathrm{ABCB} 1$ activity are consistent with the studies of Kania et al. that demonstrated a $48 \mathrm{~h}$ treatment with $25 \mu \mathrm{g} / \mathrm{ml} \mathrm{A} \beta_{(1-42)}$ reduced rhodamine efflux in the hCMEC/D3 brain endothelial cell line [16]. The findings of the present study are also consistent with those of Kuhnke et al. who reported $A \beta_{(1-42)}$, at $25 \mu \mathrm{g} / \mathrm{ml}$, reduced rhodamine efflux in membrane vesicles isolated from LLC-MDR1 cells [8], and with those of Lam et al. 2001, who reported $\mathrm{A} \beta_{(1-42)}$, at $100 \mu \mathrm{g} / \mathrm{ml}$, significantly inhibited uptake of $\left[{ }^{3} \mathrm{H}\right]$ colchicine by $\mathrm{ABCB} 1$ in inverted membrane vesicles isolated from mdr1 overexpressing $\mathrm{CH}^{\mathrm{R}} \mathrm{B} 30$ Chinese hamster ovary cells [15].

In the current study, similar reductions in ABCB1 activity were observed following $1 \mathrm{~h}$ and $24 \mathrm{~h}$ exposure to $\mathrm{A} \beta_{(1-42)}$ at $10 \mu \mathrm{g} / \mathrm{ml}, 25 \mu \mathrm{g} / \mathrm{ml}$ and $50 \mu \mathrm{g} / \mathrm{ml}$. Whilst significant ABCB1 inhibition was also observed following $48 \mathrm{~h}$ exposure to $25 \mu \mathrm{g} / \mathrm{ml}$ and $50 \mu \mathrm{g} / \mathrm{ml} \mathrm{A} \beta_{(1-42)}$, exposure to $A \beta_{(1-42)}$ at $10 \mu \mathrm{g} / \mathrm{ml}$ did not result in significant inhibition of $\mathrm{ABCB} 1$. This lack of inhibitory effect of $A \beta_{(1-42)}$ at $10 \mu \mathrm{g} / \mathrm{ml}$ could be explained by the fact that at $48 \mathrm{~h}$, aggregation of $A \beta_{(1-42)}$ at this lower concentration reduced the amount of $A \beta_{(1-42)}$ monomer available to directly interact with $\mathrm{ABCB} 1$. This finding is supported by the studies of Kuhnke et al. that showed $A \beta_{(1-42)}$ in the soluble form, and not the aggregated form, is transported by ABCB1 [8]. To confirm $A \beta_{(1-42)}$ peptide underwent aggregation in the cell culture conditions at the peptide concentrations employed in this study, aggregation was monitored using the Thioflavin $T$ assay. In these conditions, $A \beta_{(1-42)}$ peptide aggregation was observed at 25 $\mu \mathrm{g} / \mathrm{ml}$ and $50 \mu \mathrm{g} / \mathrm{ml}$ however, with $10 \mu \mathrm{g} / \mathrm{ml} \mathrm{A} \beta_{(1-42)}$ no time-dependent increase in fluorescence was observed, suggesting the levels of fluorescence obtained were at or near the 
sensitivity threshold of the Thioflavin $\mathrm{T}$ assay. These findings are consistent with those of Shen and Murphy 1995 who reported a significant increase in Thioflavin T fluorescence intensity when $A \beta_{(1-42)}$ is incubated over 8 days [47] and with the study of Cukalevski et al. which demonstrated $A \beta_{(1-42)}$ aggregation increased over $24 \mathrm{~h}$ [48]. Furthermore, the latter study reported the fluorescent intensity of Thioflavin $\mathrm{T}$ increased as the peptide concentration increased, which is consistent with the current findings that show the fluorescent intensity of Thioflavin $\mathrm{T}$ at each time point monitored was higher for $50 \mu \mathrm{g} / \mathrm{ml} \mathrm{A} \beta_{(1-42)}$ than $25 \mu \mathrm{g} / \mathrm{ml}$ $\mathrm{A} \beta_{(1-42) .}$

Here we report treatment of PBECs with $\mathrm{A} \beta_{(1-42)}$ at $25 \mu \mathrm{g} / \mathrm{ml}$ and $50 \mu \mathrm{g} / \mathrm{ml}$ for $24 \mathrm{~h}$ and 48 $\mathrm{h}$ significantly reduced ABCB1 expression levels. These findings are in partial agreement with those of Kania et al. who report down regulation of ABCB1 expression in hCMEC/D3 cells after $48 \mathrm{~h}$ treatment with $25 \mu \mathrm{g} / \mathrm{ml} \mathrm{A} \beta_{(1-42)}$, although no significant effect on ABCB1 expression was observed at $24 \mathrm{~h}$ exposure [16]. The effects of $A \beta_{(1-42)}$ on $\mathrm{ABCB} 1$ expression in PBECs in vitro are supported by findings in vivo which demonstrate peripherally administration of $A \beta_{(1-42)}$ leads to a reduction of $A B C B 1$ expression at the mRNA level in the mouse blood-brain barrier [49]. Furthermore, ABCB1 expression has also been reported to be reduced in the BBB of transgenic mice overexpressing human APP, compared with wild type animals [50].

Subsequently, we investigated the effects of $A \beta_{(1-42)}$ on ABCG2 activity and expression in PBECs. Here we demonstrate $A \beta_{(1-42)}$ significantly inhibits ABCG2 activity by direct inhibition (without an associated reduction in ABCG2 expression) since, in cells treated with $\mathrm{A} \beta_{(1-42)}$ for $1 \mathrm{~h}, \mathrm{ABCG} 2$ activity was significantly reduced. We believe this is the first study to report such a finding. Although $A \beta_{(1-42)}$-mediated inhibition of ABCG2 has not been previously reported, this finding can be rationalised by the fact that ABCG2 possesses broad substrate specificity which overlaps with $\mathrm{ABCB} 1$ and that $\mathrm{ABCG} 2$ and $\mathrm{ABCB} 1$ share common inhibitors. The fact that $\mathrm{A} \beta_{(1-42)}$ is an $\mathrm{ABCB} 1$ substrate and inhibitor, supports the finding that the peptide is an $\mathrm{ABCG} 2$ inhibitor. Whilst no studies to date have reported $\mathrm{A} \beta_{(1-}$ 42)-mediated inhibition of $A B C G 2$, there is evidence that $A \beta_{(1-42)}$ is an ABCG2 substrate. Tai et al. demonstrated increased intracellular accumulation of $\left[{ }^{125} \mathrm{I}\right] \mathrm{A} \beta_{(1-40)}$ in hCMEC/D3 cells treated with the ABCG2 inhibitor fumitrimorgin C [51], Xiong et al. have reported higher accumulation of intravenously administered Cy5.5-labeled $A \beta_{(1-40)}$ in Abcg2 knockout mice compared to wild type control [17], whilst Do et al demonstrated ABCG2-mediated efflux of $\left[{ }^{3} \mathrm{H}\right] \mathrm{A} \beta_{(1-40)}$ in HEK293 cells stably transfected with human $A B C G 2$ cDNA [52]. 
As with ABCB1, the significant decrease in ABCG2 activity following $24 \mathrm{~h}$ and $48 \mathrm{~h}$ exposure to $A \beta_{(1-42)}$ is expected to be the result of a combination of the inhibition of $A B C G 2$ activity and reduction of ABCG2 expression. Findings of the effects of $A \beta_{(1-42)}$ on ABCG2 expression reported in the literature are conflicting. Our findings contrast those of Kania et al. which demonstrated no clear change in ABCG2 expression in hCMEC/D3 cells after

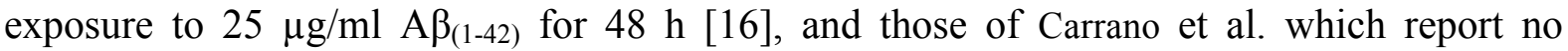
alterations in ABCG2 mRNA levels in hCMEC/D3 cells after $24 \mathrm{~h}$ exposure to $\mathrm{A} \beta_{(1-42)}$ oligomers and fibrils, however the effect of monomeric $A \beta_{(1-42)}$ was not investigated [53]. The difference in findings may be due to the fact that the current studies employed primary porcine brain endothelial cells whilst the above studies used the immortalised human hCMEC/D3 endothelial cell line in which CAR and PXR are barely detectable [54]. Furthermore, whilst in vivo studies report levels of abcg2 RNA were not affected in the brains of mice following subcutaneous administration of $A \beta_{(1-42)}$ [48], up-regulation of ABCG2 expression has been reported in brains from individuals with Alzheimer's disease [17].

In this study we report $A \beta_{(1-42)}$, at $25 \mu \mathrm{g} / \mathrm{ml}$ and $50 \mu \mathrm{g} / \mathrm{ml}$, significantly decreases ABCC5 activity in PBECs. This is the first study to demonstrate $A \beta_{(1-42)}$-mediated inhibition of $\mathrm{ABCC}$, and this inhibition can be explained by the fact that, like ABCB1 and ABCG2, ABCC5 demonstrates broad substrate specificity and that the $A \beta_{(1-42)}$ substrate inhibits GSMF transport, possibly by competitive inhibition. This finding is supported by the fact that $\mathrm{A} \beta_{(1-42)}$ is a substrate for another member of the $\mathrm{ABC}$ subclass of transporters, namely abcc 1 since, in a mouse model of Alzheimer's disease with a deficiency in abcc1, increased cerebral $\mathrm{A} \beta_{(1-42)}$ levels were observed [55].

In the current study treatment of PBECs with $A \beta_{(1-42)}$ at $25 \mu \mathrm{g} / \mathrm{ml}$ and $50 \mu \mathrm{g} / \mathrm{ml}$ for $24 \mathrm{~h}$ and $48 \mathrm{~h}$ significantly reduced ABCC5 expression levels. Whilst this is the first study to demonstrate an $\mathrm{A} \beta_{(1-42)}$-mediated reduction in ABCC5 expression, it is consistent with findings that $A \beta_{(1-42)}$ reduces expression of the $\mathrm{ABCB} 1$ efflux transporter $[16,49,50]$.

The findings that $A \beta_{(1-42)}$ significantly reduces $\mathrm{ABCB} 1, \mathrm{ABCG} 2$ and $\mathrm{ABCC} 5$ expression suggest coordination of $A \beta_{(1-42)}$-mediated regulation of $\mathrm{ABC}$ efflux transporters in primary porcine blood-brain barrier endothelial cells. The pregnane $\mathrm{X}$ receptor and constitutive androstane receptor have been reported to regulate $\mathrm{ABCB} 1$ and $\mathrm{ABCG} 2$ expression at the $\mathrm{BBB}$ by binding to response elements in the promoter regions of the $A B C B 1$ and $A B C G 2$ genes in rat [20,22], and in PBECs [56,57]. Therefore, the ability of $A \beta_{(1-42)}$ to regulate 
expression of PXR and CAR, which could subsequently impact $\mathrm{ABCB} 1$ and $\mathrm{ABCG} 2$ expression, was investigated.

Initial control studies were performed to establish the effect of the PXR ligand rifampicin on $\mathrm{ABCB} 1$ and $\mathrm{ABCG} 2$ expression and activity in PBECs. Rifampicin significantly increased both $\mathrm{ABCB} 1$ and $\mathrm{ABCG} 2$ expression and function, (data not shown), indicating expression of functional PXR in the PBECs employed in this study. This finding is similar to that of Ott et al. which reported rifampicin-induced $\mathrm{ABCB} 1$ expression and activity in PBECs [57], and to that of Abuznait et al. which demonstrated upregulation of ABCB1 expression in LS-180 cells [58].

This is the first study to provide direct evidence that $A \beta_{(1-42)}$ significantly reduces expression of both PXR and CAR. However, this finding is supported by studies carried out using the Tg2576 transgenic mouse model of Alzheimer's disease in which human amyloid precursor protein (hAPP) is overexpressed. The latter study reports expression of pxr protein in brain capillaries of Tg2576 transgenic mice, was lower than in control mice [59], which can be explained by the fact that high levels of hAPP are processed to $A \beta_{(1-42)}$, which subsequently reduces pxr expression.

The findings of the current study suggest $A \beta_{(1-42)}$ significantly inhibits activities of $B B B$ $\mathrm{ABCB} 1, \mathrm{ABCC} 5$ and $\mathrm{ABCG} 2$, and modulates expression of components of their regulatory pathway. $\mathrm{A} \beta_{(1-42)}$ therefore has the potential to impact on penetration of $\mathrm{ABC}$ transporter substrates, including many therapeutic drugs, across the BBB. Moreover, given that $A \beta_{(1-42)}$ is an $\mathrm{ABCB} 1$ substrate and that $\mathrm{ABCB} 1$-mediated amyloid- $\beta$ efflux represents a clearance pathway for removal of amyloid- $\beta$ from the brain, increased $A \beta_{(1-42)}$ production during Alzheimer's disease may interfere with this clearance mechanism.

\section{Acknowledgments}

Maryam Shubbar (1560) is funded by The Iraqi Ministry of Higher Education and Scientific Research. The authors would like to thank Dr. Pablo Torres-Vergara, Department of Pharmacy, Faculty of Pharmacy, University of Concepción, Barrio Universitario, Concepción, Chile, for his technical support. 


\section{References}

[1] H. Wolburg, A. Lippoldt, Tight junctions of the blood-brain barrier: development, composition and regulation, Vascular Pharmacology 38 (2002) 323-337.

[2] E. Urich, S.E. Lazic, J. Molnos, I. Wells, P.-O. Freskgård, Transcriptional profiling of human brain endothelial cells reveals key properties crucial for predictive in vitro blood-brain barrier models, PLoS One 7 (2012) e38149.

[3] R.N. Montesinos, B. Moulari, J. Gromand, A. Beduneau, A. Lamprecht, Y. Pellequer, Coadministration of P-glycoprotein modulators on loperamide pharmacokinetics and brain distribution, Drug metabolism and disposition: the biological fate of chemicals 42 (2014) 700.

[4] M. King, W. Su, A. Chang, A. Zuckerman, G.W. Pasternak, Transport of opioids from the brain to the periphery by P-glycoprotein: peripheral actions of central drugs, Nature Neuroscience 4 (2001) 268.

[5] F.E. O'Brien, G. Clarke, P. Fitzgerald, T.G. Dinan, B.T. Cryan, J.F. O'Brien, J.F. Griffin, J.F. Clarke, J.F. Dinan, J.F. Cryan, Inhibition of P-glycoprotein enhances transport of imipramine across the blood-brain barrier: Microdialysis studies in conscious freely moving rats, British Journal of Pharmacology 166 (2012) 1333-1343.

[6] V.G. Moisiadis, S.G. Matthews, Glucocorticoids and fetal programming part 1: outcomes, Nature Reviews Endocrinology 10 (2014) 391.

[7] J.F. Watchko, M.J. Daood, T.W. Hansen, Brain bilirubin content is increased in P-glycoproteindeficient transgenic null mutant mice, Pediatric research 44 (1998) 763.

[8] D. Kuhnke, G. Jedlitschky, M. Grube, H.K. Kroemer, M. Krohn, R.W. Warzok, S. Vogelgesang, M. Jucker, I. Mosyagin, I. Cascorbi, L.C. Walker, MDR1-P-glycoprotein (ABCB1) mediates transport of Alzheimer's amyloid- $\beta$ peptides - Implications for the mechanisms of $A \beta$ clearance at the blood-brain barrier, Brain Pathology 17 (2007) 347-353.

[9] H. Zhang, Y.-W. Zhang, H. Xu, Q. Ma, Proteolytic processing of Alzheimer's $\beta$-amyloid precursor protein, Journal of Neurochemistry 120 (2012) 9-21.

[10] H.S. Sharma, A. Sharma, R.J. Castellani, M.A. Smith, The Blood-Brain Barrier in Alzheimer's Disease. Novel Therapeutic Targets and Nanodrug delivery, International Review of Neurobiology 102 (2012) 47-90.

[11] J. Götz, A. Eckert, M. Matamales, L. Ittner, X. Liu, Modes of A $\beta$ toxicity in Alzheimer's disease, Cellular and Molecular Life Sciences 68 (2011) 3359-3375.

[12] R. Deane, S. Du Yan, R.K. Submamaryan, B. LaRue, S. Jovanovic, E. Hogg, D. Welch, L. Manness, C. Lin, J. Yu, H. Zhu, J. Ghiso, B. Frangione, A. Stern, A.M. Schmidt, D.L. Armstrong, B. Arnold, B. Liliensiek, P. Nawroth, F. Hofman, M. Kindy, D. Stern, B. Zlokovic, RAGE mediates amyloidbeta peptide transport across the blood-brain barrier and accumulation in brain, Nature medicine 9 (2003) 907-913.

[13] R. Demattos, K. Bales, D. Cummins, S. Paul, D. Holtzman, Brain to plasma amyloid- beta efflux: a measure of brain amyloid burden in a mouse model of Alzheimer's Disease, Science (Washington) 295 (2002) 2264-2267.

[14] B.V. Zlokovic, Neurovascular mechanisms of Alzheimer's neurodegeneration, Trends in Neurosciences 28 (2005) 202-208.

[15] F. Lam, R. Liu, P. Lu, A.B. Shapiro, J.M. Renoir, F. Sharom, P. Reiner, beta -Amyloid efflux mediated by p-glycoprotein, Journal of Neurochemistry 76 (2001) 1121-1128.

[16] K.D. Kania, H.C. Wijesuriya, S.B. Hladky, M.A. Barrand, Beta amyloid effects on expression of multidrug efflux transporters in brain endothelial cells, Brain research 1418 (2011) 1-11.

[17] H. Xiong, D. Callaghan, A. Jones, J. Bai, I. Rasquinha, C. Smith, K. Pei, D. Stanimirovic, W. Zhang, D. Walker, L.-F. Lue, ABCG2 is upregulated in Alzheimer's brain with cerebral amyloid 
angiopathy and may act as a gatekeeper at the blood-brain barrier for A $1-40$ peptides, Journal of Neuroscience 29 (2009) 5463-5475.

[18] S. Dauchy, F. Dutheil, R.J. Weaver, F. Chassoux, C. Daumas-Duport, P.O. Couraud, J.M. Scherrmann, I. De Waziers, X. Declèves, ABC transporters, cytochromes P450 and their main transcription factors: expression at the human blood-brain barrier, Journal of neurochemistry 107 (2008) 1518-1528.

[19] A. Nannelli, F. Rossignolo, R. Tolando, P. Rossato, M. Pellegatti, V. Longo, P.G. Gervasi, Expression and distribution of CYP3A genes, CYP2B22, and MDR1, MRP1, MRP2, LRP efflux transporters in brain of control and rifampicin-treated pigs, Molecular and Cellular Biochemistry 337 (2010) 133-143.

[20] V.S. Narang, C. Fraga, N. Kumar, J. Shen, S. Throm, C.F. Stewart, C.M. Waters, Dexamethasone increases expression and activity of multidrug resistance transporters at the rat blood-brain barrier, American Journal of Physiology-Cell Physiology 295 (2008) C440-C450.

[21] X. Ma, J.R. Idle, F.J. Gonzalez, The pregnane X receptor: from bench to bedside, Expert opinion on drug metabolism \& toxicology 4 (2008) 895-908.

[22] B. Bauer, A.M. Hartz, G. Fricker, D.S. Miller, Pregnane X receptor up-regulation of P-glycoprotein expression and transport function at the blood-brain barrier, Molecular pharmacology 66 (2004) 413-419.

[23] R.A. Skinner, R.M. Gibson, N.J. Rothwell, E. Pinteaux, J.I. Penny, Transport of interleukin-1 across cerebromicrovascular endothelial cells, British Journal of Pharmacology 156 (2009) 11151123.

[24] C.A. Cantrill, J.I. Penny, R.A. Skinner, N.J. Rothwell, An immortalised astrocyte cell line maintains the in vivo phenotype of a primary porcine in vitro blood-brain barrier model, Brain research 1479 (2012) 17-30.

[25] P. Torres-Vergara, J. Penny, Pro-inflammatory and anti-inflammatory compounds exert similar effects on P-glycoprotein in blood-brain barrier endothelial cells, Journal of Pharmacy and Pharmacology (2018).

[26] L. Rubin, D. Hall, S. Porter, K. Barbu, C. Cannon, H.C. Horner, M. Janatpour, C.W. Liaw, K. Manning, J. Morales, L.I. Tanner, K. Tomaselli, F. Bard, A cell-culture model of the bloodbrain-barrier, Journal of Cell Bioliology 115 (1991) 1725-1735.

[27] H. Gutmann, M. Török, G. Fricker, J. Huwyler, C. Beglinger, J. Drewe, Modulation of multidrug resistance protein expression in porcine brain capillary endothelial cells in vitro, Drug Metabolism and Disposition 27 (1999) 937-941.

[28] D.J. Hawthorne, G.P. Dively, Killing them with kindness? In-hive medications may inhibit xenobiotic efflux transporters and endanger honey bees, PLoS One 6 (2011) e26796.

[29] B. Poller, J. Drewe, S. Krahenbuhl, J. Huwyler, H. Gutmann, Regulation of BCRP (ABCG2) and Pglycoprotein (ABCB1) by cytokines in a model of the human blood-brain barrier, Cellular and Molecular Neurobiology 30 (2010) 63-70.

[30] B. Poller, H. Gutmann, S. Krahenbuhl, B. Weksler, I. Romero, P.O. Couraud, G. Tuffin, J. Drewe, J. Huwyler, The human brain endothelial cell line hCMEC/D3 as a human blood-brain barrier model for drug transport studies, Journal of Neurochemistry 107 (2008) 1358-1368.

[31] G. Repetto, A. Del Peso, J.L. Zurita, Neutral red uptake assay for the estimation of cell viability/cytotoxicity, Nature protocols 3 (2008) 1125.

[32] N. Kokkoni, K. Stott, H. Amijee, J.M. Mason, A.J. Doig, N-Methylated peptide inhibitors of betaamyloid aggregation and toxicity. Optimization of the inhibitor structure, Biochemistry 45 (2006) 9906-9918.

[33] M.M. Bradford, A rapid and sensitive method for the quantitation of microgram quantities of protein utilizing the principle of protein-dye binding, Analytical Biochemistry 72 (1976) 248254. 
[34] M. Bartolini, C. Bertucci, M.L. Bolognesi, A. Cavalli, C. Melchiorre, V. Andrisano, Insight Into the Kinetic of Amyloid $\beta$ (1-42) Peptide Self-Aggregation: Elucidation of Inhibitors' Mechanism of Action, ChemBioChem 8 (2007) 2152-2161.

[35] C. Zhang, X. Wan, X. Zheng, X. Shao, Q. Liu, Q. Zhang, Y. Qian, Dual-functional nanoparticles targeting amyloid plaques in the brains of Alzheimer's disease mice, Biomaterials 35 (2014) 456-465.

[36] R. Bendayan, G. Lee, M. Bendayan, Functional expression and localization of P-glycoprotein at the blood brain barrier, Microscopy Research and Technique 57 (2002) 365-380.

[37] T. Eisenblatter, S. Huwel, H.J. Galla, Characterisation of the brain multidrug resistance protein (BMDP/ABCG2/BCRP) expressed at the blood-brain barrier, Brain Research 971 (2003) 221231.

[38] M.S. Warren, N. Zerangue, K. Woodford, L.M. Roberts, E.H. Tate, B. Feng, C. Li, T.J. Feuerstein, J. Gibbs, B. Smith, Comparative gene expression profiles of $A B C$ transporters in brain microvessel endothelial cells and brain in five species including human, Pharmacological Research 59 (2009) 404-413.

[39] Y. Zhang, H. Han, W.F. Elmquist, D.W. Miller, Expression of various multidrug resistanceassociated protein (MRP) homologues in brain microvessel endothelial cells, Brain Research 876 (2000) 148-153.

[40] A.T. Nies, G. Jedlitschky, J. König, C. Herold-Mende, H.H. Steiner, H.P. Schmitt, D. Keppler, Expression and immunolocalization of the multidrug resistance proteins, MRP1-MRP6 (ABCC1-ABCC6), in human brain, Neuroscience 129 (2004) 349-360.

[41] Y. Kubo, S. Ohtsuki, Y. Uchida, T. Terasaki, Quantitative determination of luminal and abluminal membrane distributions of transporters in porcine brain capillaries by plasma membrane fractionation and quantitative targeted proteomics, Journal of Pharmaceutical Sciences 104 (2015) 3060-3068.

[42] M. Smith, Y. Omidi, M. Gumbleton, Primary porcine brain microvascular endothelial cells: Biochemical and functional characterisation as a model for drug transport and targeting, J. Drug Target. 15 (2007) 253-268.

[43] B. Steglich, A. Mahringer, Y. Li, G. Posner, G. Fricker, T. Efferth, Inhibition of P-glycoprotein by two artemisinin derivatives, Natural Products and Bioprospecting 2 (2012) 59-64.

[44] A. Mahringer, J. Delzer, G. Fricker, A fluorescence-based in vitro assay for drug interactions with breast cancer resistance protein (BCRP, ABCG2), European Journal of Pharmaceutics and Biopharmaceutics 72 (2009) 605-613.

[45] N. Ketabi-Kiyanvash, C. Herold-Mende, F. Kashfi, S. Caldeira, M. Tommasino, W.E. Haefeli, J. Weiss, NKIM-6, a new immortalized human brain capillary endothelial cell line with conserved endothelial characteristics, Cell and Tissue Research 328 (2007) 19-29.

[46] S. Marco, S.D. Skaper, Amyloid $\beta$-peptide1-42 alters tight junction protein distribution and expression in brain microvessel endothelial cells, Neuroscience Letters 401 (2006) 219-224.

[47] C.-L. Shen, R.M. Murphy, Solvent effects on self-assembly of beta-amyloid peptide, Biophysical journal 69 (1995) 640-651.

[48] R. Cukalevski, X. Yang, G. Meisl, U. Weininger, K. Bernfur, B. Frohm, T.P.J. Knowles, S. Linse, The Abeta40 and Abeta42 peptides self-assemble into separate homomolecular fibrils in binary mixtures but cross-react during primary nucleation, Chemical Science 6 (2015) 4215-4233.

[49] A. Brenn, M. Grube, M. Peters, A. Fischer, G. Jedlitschky, H.K. Kroemer, R.W. Warzok, S. Vogelgesang, Beta-amyloid downregulates MDR1-P-glycoprotein (Abcb1) expression at the blood-brain barrier in mice, International Journal of Alzheimer's Disease 2011 (2011).

[50] A.M.S. Hartz, D.S. Miller, B. Bauer, Restoring blood-brain barrier P-glycoprotein reduces brain amyloid- $\beta$ in a mouse model of Alzheimer's disease, Molecular pharmacology 77 (2010) 715723. 
[51] L. Tai, A. Loughlin, D. Male, I. Romero, P-glycoprotein and breast cancer resistance protein restrict apical-to-basolateral permeability of human brain endothelium to amyloid-beta, Journal of Cerebral Blood Flow \& Metabolism 29 (2009) 1079-1083.

[52] T.M. Do, M.-S. Noel-Hudson, S. Ribes, C. Besengez, M. Smirnova, S. Cisternino, M. Buyse, F. Calon, G. Chimini, H. Chacun, ABCG2-and ABCG4-mediated efflux of amyloid- $\beta$ peptide 1-40 at the mouse blood-brain barrier, Journal of Alzheimer's Disease 30 (2012) 155-166.

[53] A. Carrano, H. Snkhchyan, G. Kooij, S. van der Pol, J. van Horssen, R. Veerhuis, J. Hoozemans, A. Rozemuller, H.E. de Vries, ATP-binding cassette transporters P-glycoprotein and breast cancer related protein are reduced in capillary cerebral amyloid angiopathy, Neurobiol Aging 35 (2014) 565-575.

[54] S. Dauchy, F. Miller, P.-O. Couraud, R.J. Weaver, B. Weksler, I.-A. Romero, J.-M. Scherrmann, I. De Waziers, $X$. Declèves, Expression and transcriptional regulation of $A B C$ transporters and cytochromes P450 in hCMEC/D3 human cerebral microvascular endothelial cells, Biochemical Pharmacology 77 (2009) 897-909.

[55] M. Krohn, C. Lange, J. Hofrichter, K. Scheffler, J. Stenzel, J. Steffen, T. Schumacher, T. Brüning, A.-S. Plath, F. Alfen, Cerebral amyloid- $\beta$ proteostasis is regulated by the membrane transport protein ABCC1 in mice, The Journal of clinical investigation 121 (2011) 3924-3931.

[56] J. Lemmen, I.E. Tozakidis, P. Bele, H.-J. Galla, Constitutive androstane receptor upregulates Abcb1 and Abcg2 at the blood-brain barrier after CITCO activation, Brain research 1501 (2013) 68-80.

[57] M. Ott, G. Fricker, B. Bauer, Pregnane X receptor (PXR) regulates P-glycoprotein at the bloodbrain barrier: functional similarities between pig and human PXR, Journal of Pharmacology and Experimental Therapeutics 329 (2009) 141-149.

[58] A. Abuznait, C. Cain, D. Ingram, D. Burk, A. Kaddoumi, Up-regulation of P-glycoprotein reduces intracellular accumulation of beta amyloid: investigation of P-glycoprotein as a novel therapeutic target for Alzheimer's disease, Journal of Pharmacy and Pharmacology 63 (2011) 1111-1118.

[59] A. Hartz, B. Bauer, E. Soldner, A. Wolf, S. Boy, R. Backhaus, I. Mihaljevic, U. Bogdahn, H. Klunemann, G. Schuierer, F. Schlachetzki, Amyloid-beta Contributes to Blood-Brain Barrier Leakage in Transgenic Human Amyloid Precursor Protein Mice and in Humans With Cerebral Amyloid Angiopathy, Stroke 43 (2012) 514-523. 